\title{
Submarine Groundwater Discharge: Updates on Its Measurement Techniques, Geophysical Drivers, Magnitudes, and Effects
}

\begin{abstract}
Makoto Taniguchi ${ }^{1 *}$, Henrietta Dulai ${ }^{2}$, Kimberly M. Burnett ${ }^{3}$, Isaac R. Santos ${ }^{4,5}$, Ryo Sugimoto ${ }^{6}$, Thomas Stieglitz ${ }^{7,8}$, Guebuem Kim $^{9}$, Nils Moosdorf ${ }^{10}$ and William C. Burnett ${ }^{11}$

${ }^{1}$ Research Institute for Humanity and Nature, Kyoto, Japan, ${ }^{2}$ Department of Earth Sciences, University of Hawaii, Honolulu, HI, United States, ${ }^{3}$ University of Hawaii Economic Research Organization, University of Hawaii, Honolulu, HI, United States, ${ }^{4}$ National Marine Science Centre, Southern Cross University, Lismore, NSW, Australia, ${ }^{5}$ Department of Marine Sciences, University of Gothenburg, Gothenburg, Sweden, ${ }^{6}$ Research Center for Marine Bioresources, Fukui Prefectural University, Obama, Japan, ${ }^{7}$ Centre for Tropical Water and Aquatic Ecosystem Research, James Cook University, Townsville, QLD, Australia, ${ }^{8}$ Aix-Marseille Université, CNRS, IRD, INRA, Coll France, CEREGE, Aix-en-Provence, France, ${ }^{9}$ School of Earth \& Environmental Sciences/RIO, Seoul National University, Seoul, South Korea, ${ }^{10}$ Leibniz Centre for Tropical Marine Research (LG), Bremen, Germany, ${ }^{11}$ Department of Earth, Ocean and Atmospheric Science, Florida State University, Tallahassee, FL, United States
\end{abstract}

OPEN ACCESS

Edited by:

Davide Poggi,

Politecnico di Torino, Italy

Reviewed by:

Henry Bokuniewicz,

The State University of New York

(SUNY), United States

Pei Xin,

Hohai University, China

*Correspondence:

Makoto Taniguchi

makoto@chikyu.ac.jp

Specialty section:

This article was submitted to Water and Wastewater Management,

a section of the journal

Frontiers in Environmental Science

Received: 30 June 2019 Accepted: 10 September 2019

Published: 01 October 2019

Citation:

Taniguchi M, Dulai H, Burnett KM, Santos IR, Sugimoto R, Stieglitz T, Kim G, Moosdorf N and Burnett WC

(2019) Submarine Groundwater

Discharge: Updates on Its

Measurement Techniques,

Geophysical Drivers, Magnitudes, and

Effects. Front. Environ. Sci. 7:141.

doi: 10.3389/fenvs.2019.00141
The number of studies concerning Submarine Groundwater Discharge (SGD) grew quickly as we entered the twenty-first century. Many hydrological and oceanographic processes that drive and influence SGD were identified and characterized during this period. These processes included tidal effects on SGD, water and solute fluxes, biogeochemical transformations through the subterranean estuary, and material transport via SGD from land to sea. Here we compile and summarize the significant progress in SGD assessment methodologies, considering both the terrestrial and marine driving forces, and local as well as global evaluations of groundwater discharge with an emphasis on investigations published over the past decade. Our treatment presents the state-of-the-art progress of SGD studies from geophysical, geochemical, bio-ecological, economic, and cultural perspectives. We identify and summarize remaining research questions, make recommendations for future research directions, and discuss potential future challenges, including impacts of climate change on SGD and improved estimates of the global magnitude of SGD.

Keywords: submarine groundwater discharge, subterranean estuaries, geophysics, geochemistry, cultural and economic aspects

\section{INTRODUCTION}

Some material pathways from land to the sea are obvious while others are not so apparent. Rivers, for example, slowly erode the continents and carry dissolved materials from land to the ocean. This never-ending delivery of dissolved salt to the sea so impressed Joly (1899), University of Dublin, that he calculated that it would take rivers about 90 million years to deliver all the sodium dissolved in the world's oceans. He further speculated that this might be a good approximation for the age of the Earth. Of course, we now know that what he actually estimated was the residence time of sodium. Still, rivers are a major contributor of dissolved materials to the sea. But there are other contributors as well. 
Could groundwater play an important role in such landsea exchange? Terrestrial groundwater flows down-gradient and ultimately discharges into the sea (Figure 1). This process, part of what is now called "submarine groundwater discharge" (SGD) has become recognized as an important factor in land-sea exchange. While the presence of submarine springs has been known since the days of the Romans, this "invisible pathway" was neglected scientifically for many years because of the difficulty in assessment and the perception that the process was unimportant. This perception has now changed dramatically. Within the last several years there has emerged a recognition that in some cases, groundwater discharge into the sea may be both volumetrically and chemically important. The earlier views were at least partially driven by the difficulty in measuring such flows. Most large rivers are gauged, and their discharges can often be found online. While there is no direct gauge for SGD, techniques have been worked out over the last few decades that allow us to estimate these flows.

Here we define SGD as "the flow of water through continental and insular margins from the seabed to the coastal ocean, regardless of fluid composition or driving force" (Burnett et al., 2003). Note that we have added the term "insular" to the original definition. As pointed out before (Zektser and Everett, 2000; Moosdorf et al., 2015) islands typically have higher groundwater discharge fluxes per unit area of land mass than continents. Also note that since we view "groundwater" as any water in the saturated zone of geologic material (Freeze and Cherry, 1979), groundwater is here synonymous with pore water. Importantly, SGD includes waters of any salinity. In fact, fresh water from recharged aquifers on land only represents a minor portion of the total flux in many cases. Moore (2010) added a "scale length of meters to kilometers" to the earlier definition in order to separate SGD from microscale processes involving pore water exchange. A reasonable idea as the mechanisms driving the flow are very different. See further discussion on this subject in section Geophysical Processes.

Another term that has become widely used in the field is the "subterranean estuary" (STE; Moore, 1999). Basically, the STE is seen as the mixing zone between groundwater and seawater within a coastal aquifer. Within this zone, reactions occur that can substantially modify the composition of these fluids. So, while one might envision the penetration of seawater and its subsequent discharge back into the sea as "seawater recycling," the geochemical processes within the subterranean estuary may have distinctly altered the composition of the discharging water.

Since there have been a few previous reviews (e.g., Burnett et al., 2003; Moore, 2010) of SGD research, we will limit this overview to updates and refinements since about 2010. We will restrict our coverage to marine settings including the coastal zone, shelf, estuaries, and lagoons. We will include updates concerning measurements, estimates of SGD magnitudes, geochemical/ecological effects, and cultural/economic aspects. While many SGD studies have been concerned with possible chemical/ecological implications, there have also been recent efforts to evaluate the economic and cultural values associated with SGD (e.g., Michael et al., 2017; Moosdorf and Oehler, 2017; Burnett et al., 2018; Pongkijvorasin et al., 2018). There is

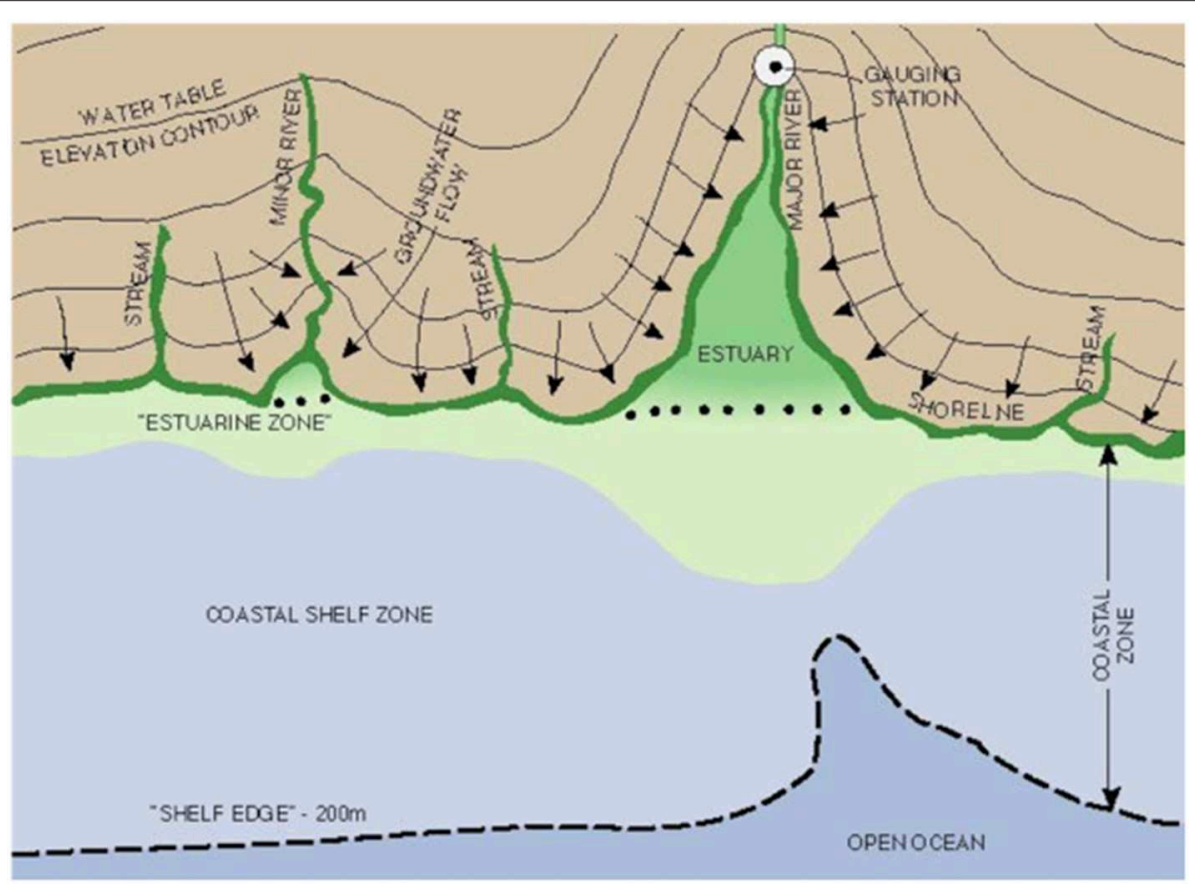

FIGURE 1 | Schematic of the coastal zone showing water table contours and terrestrial groundwater flow paths. This illustrates how groundwater flow driven by hydraulic gradients is focused in river valley estuaries and dispersed at highlands. Note that the groundwater contours and flow paths shown control only the terrestrially-driven flow. Marine, geophysical and biological forces contribute substantially to the total flow through coastal sediments. Also note that the gauging station, located well upstream to eliminate tidal effects, will miss all the groundwater discharged below the gauge (Buddemeier, 1996). 
also mounting evidence for the global occurrence of offshore fresh and brackish groundwater reserves underneath continental shelves (Post et al., 2013; Gustafson et al., 2019). Since there is no clear evidence on whether these fossil offshore aquifers are exchanging with the ocean, they are beyond our scope. However, the potential use of these non-renewable reserves as a freshwater resource does provide a clear incentive for future research.

While there was not much scientific work done specifically on SGD prior to the later part of the twentieth century, there were some attempts, many of them related to possible offshore sources of potable water. The lack of interest in the process led Fran Kohout, one of the true pioneers in the field, to comment that "...these marvels of the sea (submarine springs) are justifiably classified as neglected phenomena of coastal hydrology" (Kohout, 1966). He reported in that paper that a literature search only succeeded in finding 15 scientifically-oriented studies concerning SGD. Other early contributions included Lee (1977), Bokuniewicz (1980), Johannes (1980), and Valiela and D'Elia (1990) among others. These early researchers had the foresight to see that SGD needed increased attention. In their "Preface to a Special Issue" on groundwater discharge in the journal Biogeochemistry, Valiela and D'Elia (1990) commented that "we are very much in the exploratory stage of this field." We thus see the period before the mid-1990s as the "early days" of SGD research.

Things then started to change quickly. In the proceedings of a Land Ocean Interactions in the Coastal Zone (LOICZ) conference dedicated specifically to SGD ("Groundwater Discharge in the Coastal Zone," Moscow, July 6-10, 1996), it was stated that: "Measurements or estimates of groundwater and associated chemical fluxes, especially over substantial areas or time periods, are notoriously uncertain" (Buddemeier, 1996). Around the same time, some very interesting and provocative data started to appear. Based on large enrichments of ${ }^{226} \mathrm{Ra}$ in the shelf waters off South Carolina and Georgia, Moore (1996) concluded that the groundwater flux, largely recirculated seawater, to the shelf must be about $40 \%$ of the river flux to the same area. A few months later, Cable et al. (1996) reported that radon $\left({ }^{222} \mathrm{Rn}\right)$ was significantly enriched in the inner shelf waters of the northeastern Gulf of Mexico. Using a model based on radon inventories they calculated that within a relatively small region $\left(\sim 620 \mathrm{~km}^{2}\right)$ there was groundwater (combination of saline and fresh) flow in the range of $180-710 \mathrm{~m}^{3} / \mathrm{s}$. This is roughly equivalent to the outflow from the Apalachicola River, the largest river in Florida. The value of geochemical tracers quickly became apparent and many studies followed. During this period, which we refer to here as the "developmental period" from the mid-1990s to mid-2000s, there was substantial progress in this field. During this period there were many site studies, considerable advances in technology, more elaborate modeling efforts, and many new insights into driving forces and magnitudes of SGD. Multiple drivers of SGD became recognized (Figure 2). Teams of oceanographers and hydrologists collaborated in meetings and field efforts through sponsorship from the Scientific Committee on Oceanic Research (SCOR), UNESCO and other international agencies (Taniguchi et al., 2002; Burnett et al., 2006). New technologies for measuring geochemical tracers played a key role in getting things moving. For example, Moore and Arnold (1996) developed a

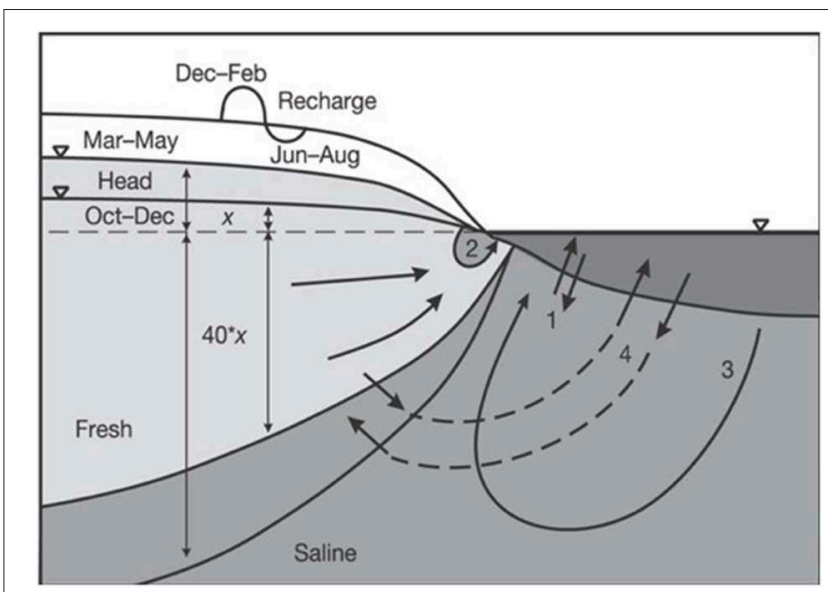

FIGURE 2 | Flow paths and some of the driving forces of SGD. Mechanisms shown include: (1) tidal pumping, (2) nearshore circulation due to tides and waves, (3) saline circulation driven by dispersive entrainment and brackish discharge, and (4) seasonal exchange (Michael et al., 2005).

coincidence counting system that made determinations of ${ }^{223} \mathrm{Ra}$ and ${ }^{224} \mathrm{Ra}$ much easier and faster. Development of an automated radon-in-water continuous monitoring system greatly simplified radon mapping in the coastal zone (Burnett et al., 2001; Dulaiova et al., 2005). Such technological advances were not limited to geochemical tools. Designs for automated seepage meters based on heat-pulse, dye-dilution, and electromagnetic principles as well as improved electrical resistivity approaches all made substantial contributions (Taniguchi and Fukuo, 1993; Krupa et al., 1998; Paulsen et al., 2001; Sholkovitz et al., 2003; Swarzenski et al., 2006).

Beginning around the mid-2000s, we entered into the "mature stage" of SGD research. SGD investigations have now advanced from hydrogeologic "curiosities" to mainstream science. The scientific community now recognizes that SGD is not only a function of the terrestrial hydraulic gradient but that marine and other drivers result in substantial flow through coastal and shelf permeable sediments. So, while the water table contours shown in Figure 1 may describe the terrestrial flow, the total flow in many cases is dominated by seawater infiltration and subsequent circulation through STEs. As pointed out in more recent reviews, the driving forces of SGD and porewater exchange overlap in both time and space (Moore, 2010; Santos et al., 2012 b). There is now widespread recognition that SGD plays an important role in the delivery of nutrients and other dissolved materials to the ocean. While SGD remains somewhat invisible, and still represents a challenge to be measured, it is no longer being overlooked.

\section{GEOPHYSICAL ASPECTS}

\section{Geophysical Processes}

Literature reviews on the physical drivers of porewater exchange (Huettel and Webster, 2000; Huettel et al., 2014) and SGD (Moore, 2010; Santos et al., 2012b; Robinson et al., 2018) are 
already available. Here, we summarize recent developments in the field and illustrate the challenges of quantifying the multiple overlapping geophysical drivers of fluid flow (Figure 3). SGD and porewater exchange, which we see as different but overlapping processes, are driven by a complex combination of processes occurring over spatial scales ranging from $\mathrm{mm}$ to $\mathrm{km}$, and temporal scales ranging from seconds to years (Santos et al., 2012b). Building on Moore's (2010) interpretation of SGD, we use length and time scales as boundaries to distinguish the terms porewater exchange and SGD (see thick line in Figure 3). Ours and Moore's (2010) definition of SGD excludes several small spatial and temporal scale processes such

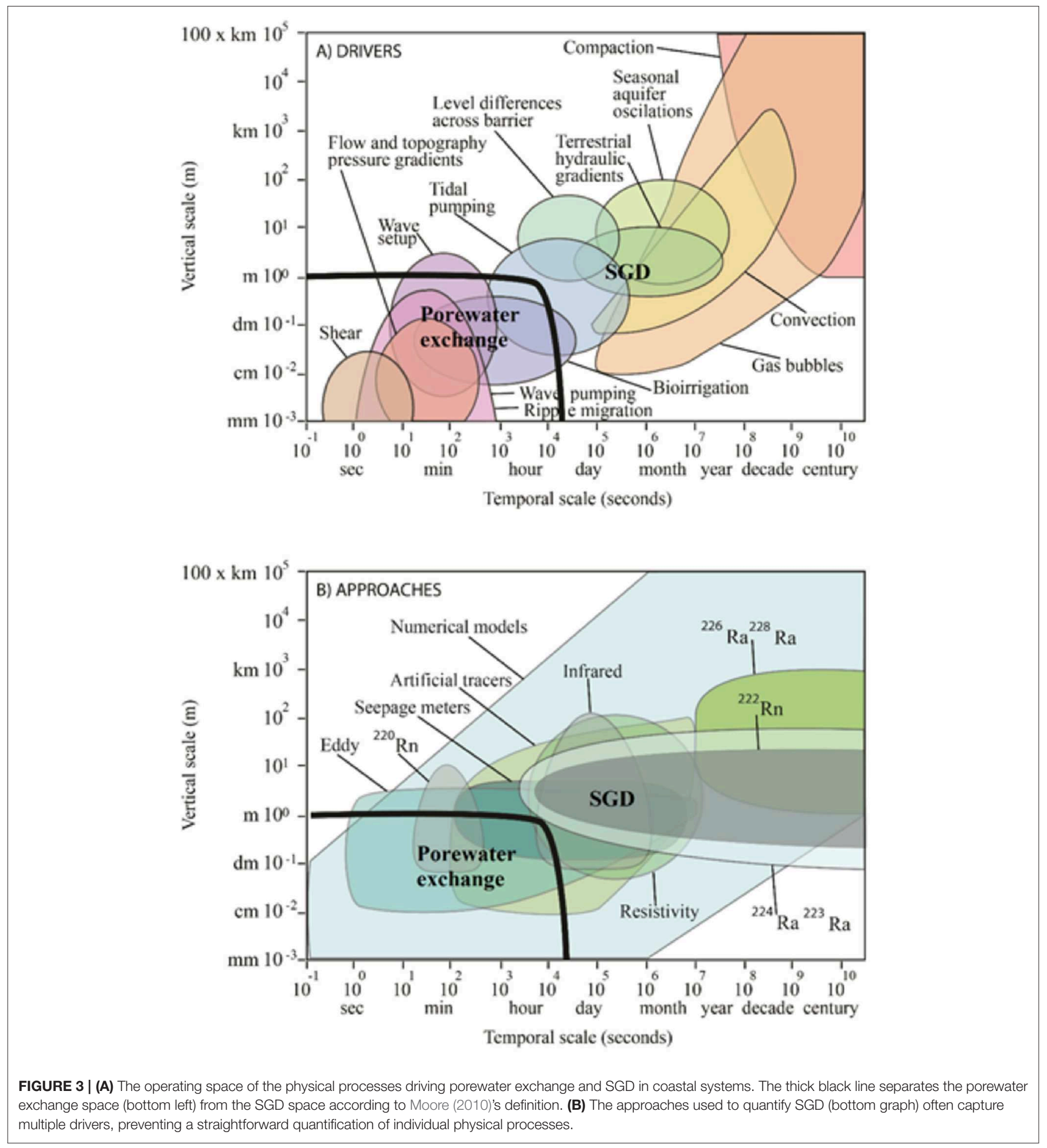


as wave pumping, flow and topographically-induced pressure gradients, and ripple migration that drive advective porewater exchange on scales of $<\mathrm{m}$ and $<$ hour. Other important processes such as tidal pumping, wave setup and bio-irrigation may be considered as porewater exchange and/or SGD depending on the context, measurement technique employed, and environmental implication of interest.

Because different techniques tend to quantify overlapping physical processes, confusion when reporting and interpreting results often prevents straightforward comparisons among different field sites and research groups. Most attempts to quantify different drivers of SGD tend to focus on a separation between fresh SGD driven by terrestrial hydraulic gradients vs. saline SGD driven by multiple marine forces. Similar to porewater exchange ( $<\mathrm{m}$ scale), saline SGD ( $>$ m scale) often has large gross yet zero net water fluxes. Earlier investigations relied on salinity observations of water collected from seepage meters to assess the relative contribution of fresh SGD to total SGD (Michael et al., 2003; Santos et al., 2009) as well as a comparison between Darcy's Law derived fresh SGD vs. total SGD derived from seepage meters (Taniguchi and Iwakawa, 2004) or geochemical tracers (Mulligan and Charette, 2006). More recent investigations have relied on a comparison of salt balance approaches (fresh SGD) vs. geochemical tracers (total SGD). For example, salinity and flow observations were used to infer fresh SGD, while a radium isotope mass balance was used to estimate tidally-driven saline SGD in Australian estuaries (Sadat-Noori et al., 2015, 2017). The different half-lives of radium isotopes have been used to broadly separate SGD from porewater exchange (Tamborski et al., 2017b, 2018).

These investigations provided widespread evidence that the volumetric contribution of fresh SGD is minor compared to saline SGD and porewater exchange at a wide range of field sites. The estimates based on multiple methods also shed light into the physical processes that may be quantified using the different measurement approaches (see overlapping areas in Figures 3A,B). Separating the relative contribution of the different physical processes driving saline SGD is important because longer residence times of seawater within sediments will have a greater impact on the geochemical composition of the exchanging seawater (Seidel et al., 2014; Tamborski et al., 2017a). The multiple time scales of marine driving forces are difficult to quantify using geochemical approaches or field observations. As a result, the roles of currents, tides, waves, and density have been explored mostly using numerical models (Li and Barry, 2000; Robinson et al., 2006; Sawyer et al., 2013).

Tidally-driven SGD has been extensively investigated following the discovery of the beach water table over-height or super-elevation (Nielsen, 1990) followed by the discovery of fresh groundwater tubes underlying upper saline plumes in beach aquifers (Robinson et al., 2006). Seawater infiltrating beaches, fractured aquifers and/or marshes at high tide creates a circulation cell that drives the return of seawater to the ocean at low tide on time scales of days to months (Robinson et al., 2009; Wilson et al., 2015; Geng and Boufadel, 2017; Santos et al., 2019). This process can account for a large fraction of SGD on a local scale, releasing solutes from the beach into the ocean. The beach water table over-height is driven by faster aquifer recharge during flood tide than discharge at ebb tide, resulting in a localized increase in beach groundwater level that can retard fresh SGD while enhancing saline SGD (Nielsen, 1999; Li et al., 2000). The upper saline plume commonly found in permeable coastal aquifers (Robinson et al., 2018) can alter density-driven seawater circulation since denser seawater overlying fresh groundwater drives convective exchange (Greskowiak, 2014; Röper et al., 2015).

Wave-driven SGD often overlaps the effects of currents and tides (Xin et al., 2010). While waves are known to play a major role in fluid exchange (Sawyer et al., 2013), field investigations have not been able to fully separate their relative contribution to total SGD. Investigations on wave-driven SGD rely on numerical models usually under ideal, phase-averaged conditions (Robinson et al., 2014). Waves expand the tidally-driven upper saline plume in beaches and enhance total SGD (Xin et al., 2010). The importance of waves driving porewater exchange is highly variable with integrated volumetric exchange rates estimated to exceed tidal pumping by one order of magnitude. During storms, wave pumping can increase by orders of magnitude exceeding all other geophysical drivers of fluid flow across the sediment-water interface (Sawyer et al., 2013). In contrast to the effects of tides that occur primarily in intertidal areas, wave-driven porewater and groundwater flow can also occur in shallow subtidal areas.

The overlapping nature of marine drivers of SGD (i.e., currents, tides, waves, density gradients) complicate the individual quantification of the specific physical drivers of SGD. The residence time of seawater circulation cells in coastal aquifers is quite variable ranging from minutes to hours when driven primarily by currents or waves (Anwar et al., 2014), hours to months when driven by tides in intertidal areas (Seidel et al., 2014) and months to thousands of years when driven by density (Post et al., 2013; Seidel et al., 2015; Michael et al., 2016). The multiple driving forces are not necessarily synergistic or additive (Robinson et al., 2018) and interact non-linearly (King, 2012; Xin et al., 2015). For example, while tidal pumping maximizes density-driven convection in intertidal aquifers, it may decrease terrestrial fresh SGD due to the localized elevation of the water table (Robinson et al., 2007). Overlapping tides and waves in numerical models resulted in lower SGD than when either tides or waves are modeled individually (Xin et al., 2010). SGD also responds to past events creating a memory effect that can modify flow for several weeks (Xin et al., 2014). Delayed SGD related to antecedent storms (Smith et al., 2008; Yu et al., 2017), seasonal changes in the terrestrial hydraulic gradient (Michael et al., 2005), and three-dimensional morphological complexities (Zhang et al., 2016) have been described, adding another dimension to the problem and complicating the assessment of the interactions between multiple forces.

Research about the physical drivers of SGD has been developed mostly in permeable sandy aquifer sites. While muddy sediments are often perceived to be impermeable, secondary permeability created by abundant animal burrows can enable advective flow in muddy mangrove and saltmarsh sediments (Xin et al., 2011; Tait et al., 2016). The burrows can connect underlying sandy aquifers containing fresh groundwater to the 
surface (Wilson et al., 2015) and enhance tidally-driven saline SGD (Xin et al., 2011; Stieglitz et al., 2013). Groundwater flows in those systems is three dimensional and highly complex due to the patchy nature of burrows, subtle geomorphological gradients, and heterogeneous sediments and vegetation (Moffett et al., 2012; Wilson and Morris, 2012; Xin et al., 2012). Radon and radium observations in multiple mangrove creeks revealed tidally-driven porewater exchange ranging from 2 to $35 \mathrm{~cm} /$ day (Tait et al., 2016, 2017). If extrapolated to the global mangrove area, these exchange rates would be enough to filter the entire continental shelf volume in $\sim 150$ years and are equivalent to $\sim 1 / 3$ of the annual volume of river water entering the oceans (Tait et al., 2016). Because mangrove and saltmarsh porewaters are often highly enriched in carbon and greenhouse gases (Santos et al., 2019), the input of dissolved carbon to the oceans via mangroves may be comparable to the input from global rivers (Chen et al., 2018b). Therefore, muddy mangrove and saltmarsh systems that are widespread on global shorelines deserve additional attention and may disproportionally contribute to SGD and related biogeochemical inputs to the ocean.

High salinity SGD has also been shown in some deltas. For example, Xu et al. $(2013,2014)$ used radium isotopes to quantify SGD fluxes in the Yellow River Delta. They estimated a SGD flux of $1.3 \times 10^{9} \mathrm{~m}^{3} \mathrm{~d}^{-1}$ with a range of $2.8 \times 10^{8}-3.0 \times 10^{9} \mathrm{~m}^{3} \mathrm{~d}^{-1}$. Even the minimum SGD value was about 3 times higher than the Yellow River discharge at that time. The SGD input of dissolved nutrients was shown to be at least 5 times higher than river input.

\section{Geophysical Methodology}

To date, the most commonly applied approaches to quantify SGD fluxes provide estimates over a wide spatial range (Figure 3). A significant gap remains between "embayment-scale" or "beachscale" geochemical flux estimates on one hand, and seepage meter point measurements on the other. Geophysical methods have been increasingly applied in recent years in order to bridge this gap. The most common geophysical tools applied in SGD studies thus far are based on temperature and salinity variations. In contrast to many geochemical tracer approaches, geophysical approaches can discriminate between freshwater and saline components of SGD (e.g., Stieglitz et al., 2008a; Tamborski et al., 2015). Particularly applicable to point sources of freshwater SGD, e.g., karstic or volcanic origin, where considerable spatial contrasts in these parameters exist, these approaches provide a "map," but do not allow for a quantification of SGD fluxes without combining with other methods.

\section{Detection of SGD Sites by Thermal Infrared Sensing}

Digital thermal infrared cameras are increasingly accessible in price and size, which has resulted in a significant rise in their application over the past decade. By mapping sea surface temperatures with a thermal infrared (TIR) sensor, plumes of buoyant low-density (fresh/brackish) groundwater can be detected. Locations of groundwater discharge are inferred from temperature anomalies (either low or high), based on the seasonal contrast between groundwater and ocean temperature (e.g., Varma et al., 2010). Often, TIR observations are used as a guide to target subsequent sampling by quantitative methods (e.g.,
Mulligan and Charette, 2006; Röper et al., 2014). On large spatial scales (km-scale), readily available space borne remote sensing TIR data can be used to identify large SGD inflows sustaining persistent temperature plumes, e.g., in Geographe Bay, Western Australia (Varma et al., 2010), in Java, Indonesia (Oehler et al., 2018), and along the Irish coast (Wilson and Rocha, 2012). TIR cameras are most often mounted on light aircraft (Duarte et al., 2006; Johnson et al., 2008; Lee et al., 2016a; Bejannin et al., 2017) and more recently on drones (e.g., Lee et al., 2016b) with a typical temperature resolution of $0.1^{\circ} \mathrm{C}$ at a spatial resolution down to $0.5 \mathrm{~m}$ (e.g., Johnson et al., 2008; Kelly et al., 2013). An oftenoverlooked application is the simple handheld use of an infrared camera, which for instance allows the rapid identification of $\mathrm{cm}$-scale groundwater springs at low tide in the intertidal zone (Röper et al., 2014). Some studies suggest that the surface area of a sea surface temperature plume can be used to quantify SGD fluxes (e.g., Kelly et al., 2013; Tamborski et al., 2015). This is based on the assumption that the 3D structure of the plume is known or can be estimated. However, Lee et al. (2016a) illustrate the often non-consistent shape of SGD plumes by multiple aerial surveys over a range of seasons and tidal stages. This inherent limitation of surface remote sensing approaches in oceanography is welldocumented (e.g., river plumes, Burrage et al., 2003). While there are inherent limitations in using the non-conservative tracer heat/temperature for SGD studies (SGD is not the only "source" of temperature anomalies), this approach has today become a popular part of the SGD toolkit owing to the availability of affordable sensors. Multispectral and hyperspectral sensors are becoming increasingly accessible and may see wider application in the near future. For example, mapping of turbidity plumes caused by sediment remobilization due to groundwater inflow (Kolokoussis et al., 2011). Sea surface salinity would also be an ideal parameter to map and quantify freshwater inflow, but available operational satellite products (SMOS) to date do not have the appropriate resolution for nearshore processes, and airborne low-frequency microwave radiometer sensors remain rare (e.g., Burrage et al., 2003).

\section{Mapping the Subterranean Estuary With Electrical Ground Conductivity}

Early studies of SGD often provided diverse results between "downscaled" geochemical flux estimates and "upscaled" point measurements as, for example, obtained by seepage meters. This is particularly the case where flow patterns are affected by natural or artificial preferential flow paths. While this scale gap remains, it has been significantly reduced over the past decade thanks to advances in a range of additions to the SGD toolkit, including geoelectric methods. When referring to "geoelectric methods," the terms bulk/ground (electrical) ground conductivity, resistivity (the inverse of conductivity), and electrical tomography are used in the literature. They all refer to basically the same approach, albeit using slightly different instrumentation. The electrical conductivity (resistivity) of coastal sediments is a function of the soil porosity (or pore water fraction) and of the salinity (and temperature) of the interstitial water. In SGD studies, spatial variations of pore water salinity close to the fresh-salt interface are significantly 
greater than those of porosity. Geoelectric instrumentation consist of an array of multiple electrodes (minimum four), either directly inserted into the ground (e.g., Stieglitz et al., 2008a), deployed on the sediment surface (e.g., Breier et al., 2005; Swarzenski et al., 2006) or, in some cases, towed behind a boat (Manheim et al., 2004; Su et al., 2014). The geometry of the electrode array determines the volume of sediment over which conductivity/resistivity will be averaged (e.g., Stieglitz et al., 2008b; Henderson et al., 2009).

Geoelectric mapping helps to improve SGD field studies by, for example, informing a more representative placement of seepage meters where preferential flow paths persist (Stieglitz et al., 2007, 2008b). It allows upscaling of point measurements to beach-scale fluxes (Stieglitz et al., 2008a), and repeated measurements along the same transects document the temporal variability of the fresh-salt interface and of fresh groundwater and seawater recirculation fluxes (Taniguchi et al., 2008; Bighash and Murgulet, 2015). They can also be used for the establishment of a sub-surface salt balance model from which SGD fluxes can be calculated (Dimova et al., 2011; Bighash and Murgulet, 2015).

Surface-deployed electrodes and an inversion calculation can be used to obtain a $2 \mathrm{D}$ resistivity section with a vertical penetration about one order of magnitude less than the horizontal extension of the array (e.g., $10 \mathrm{~m}$ depth along a $100 \mathrm{~m}$ transect), at a spatial resolution on the order of a few meters. Using this approach, Taniguchi et al. (2006) demonstrated that freshwater SGD rates were highest just landward of the saltwater-freshwater interface on a beach in Japan. Gilfedder et al. (2015) showed that a considerable increase in groundwater flux followed storm events on an Australian coastal wetland. Geoelectrical methods are particularly useful to document the temporal dynamics of SGD fluxes and the freshwater-saltwater interface in the subterranean estuary. For example, resistivity mapping on Ubatuba beach (Brazil) showed that the freshwater-saltwater interface moved offshore during a rising tide, in the opposite direction as would be expected, indicating that preferential flow in the fractured rock aquifer was a more important driver of SGD flux than tidal water level fluctuations at this site (Taniguchi et al., 2008).

While interpretation of in situ profile data is straight-forward, uncertainties in both data acquisition (e.g., survey geometry, land topography) and processing (e.g., inversion artifacts, choice of interpolation method) can produce suboptimal results in resistivity inversion calculations of surface arrays (Henderson et al., 2009). These errors can be addressed to some degree by careful ground-truthing (including vertical direct profiling and borehole data) and fine-tuning of the model inversions to the specific characteristics of a field site including sediment type and distribution (Henderson et al., 2009; Johnson et al., 2015). The coupling of geoelectric data and hydrogeological density-driven flow modeling will likely be used more extensively in the future to improve our understanding of the complex and dynamic mixing processes between fresh and saline groundwaters at their interface (Robinson et al., 2006).
Seafloor Mapping and Sub-bottom (seismic) Profiling Similar to other forms of subsurface fluid flow, SGD can affect seafloor morphology. Acoustic seafloor mapping tools (multibeam echosounders and sidescan sonar) providing high resolution maps of the seafloor have revealed the locations of seafloor structures associated with SGD, e.g., "Wonky Holes" (Stieglitz, unpublished data). These seafloor depressions have a diameter of 10 to $30 \mathrm{~m}$ and a depth of up to $4 \mathrm{~m}$ below surrounding water depths of around $20 \mathrm{~m}$. These features lie some $10 \mathrm{~km}$ offshore from the Great Barrier Reef coastline (Stieglitz and Ridd, 2000; Stieglitz, 2005). Schlüter et al. (2004) and Rousakis et al. (2014) mapped pockmarks in the Baltic and Mediterranean Sea, resulting from the interaction between sediment fluidization and bottom currents and subaqueous limestone formation (karstification). The investigation of subsurface geological structures by seismic profiling can be instructive to determine the geological origin of SGD and its flow paths (Evans and Lizarralde, 2003; Viso et al., 2010). For example, seismic profiling data suggests that submarine paleochannels, infilled with permeable sediments and capped with impermeable material provide a hydrological connection of coastal aquifers with offshore discharge sites. Thus, providing preferential flow paths for SGD as interpreted from observations along the Great Barrier Reef (Stieglitz and Ridd, 2000; Stieglitz, 2005) and offshore at Wrightsville Beach, USA (Mulligan et al., 2007). In some cases SGD appears to be controlled by fault lines or fracture patterns (Bokuniewicz et al., 2008). A few examples of results from these approaches are shown in Figure 4.

\section{GEOCHEMICAL ASPECTS}

\section{Geochemical Processes}

The discharge of meteoric groundwater and salty groundwater generally show distinctively different geochemical characteristics. The direct discharge of meteoric groundwater may reflect geochemical characteristics of fresh groundwater, which depend on local hydrogeologic conditions and anthropogenic perturbations. In contrast, the discharge of salty groundwater, which may be composed exclusively of recirculated seawater or a composite of meteoric groundwater and seawater, goes through vigorous biogeochemical alterations in the subterranean estuary (STE) (Santos et al., 2008).

Geochemical processes in the STE are very different from those observed in river estuaries in many respects. The most distinct difference is the fact that the ratio of solid to liquid in a STE is much higher than that in river estuaries. Therefore, reactive elements can be more easily removed, and $\mathrm{pH}$ may be enhanced due to the adsorption of $\mathrm{H}+$ on oxide surfaces in an organic-poor STE (Lee and Kim, 2015) or reduced due to production of $\mathrm{CO}_{2}$ during organic matter respiration (Cyronak et al., 2014). In an organic-rich STE, various remineralized components of organic matter, including nutrients, dissolved organic carbon (DOC), dissolved inorganic carbon (DIC), fluorescent dissolved organic matter, and trace elements, are highly enriched and $\mathrm{pH}$ is generally lower. The temperature of groundwater is relatively constant compared with surface waters, especially in temperate regions. In addition, STE waters are often 

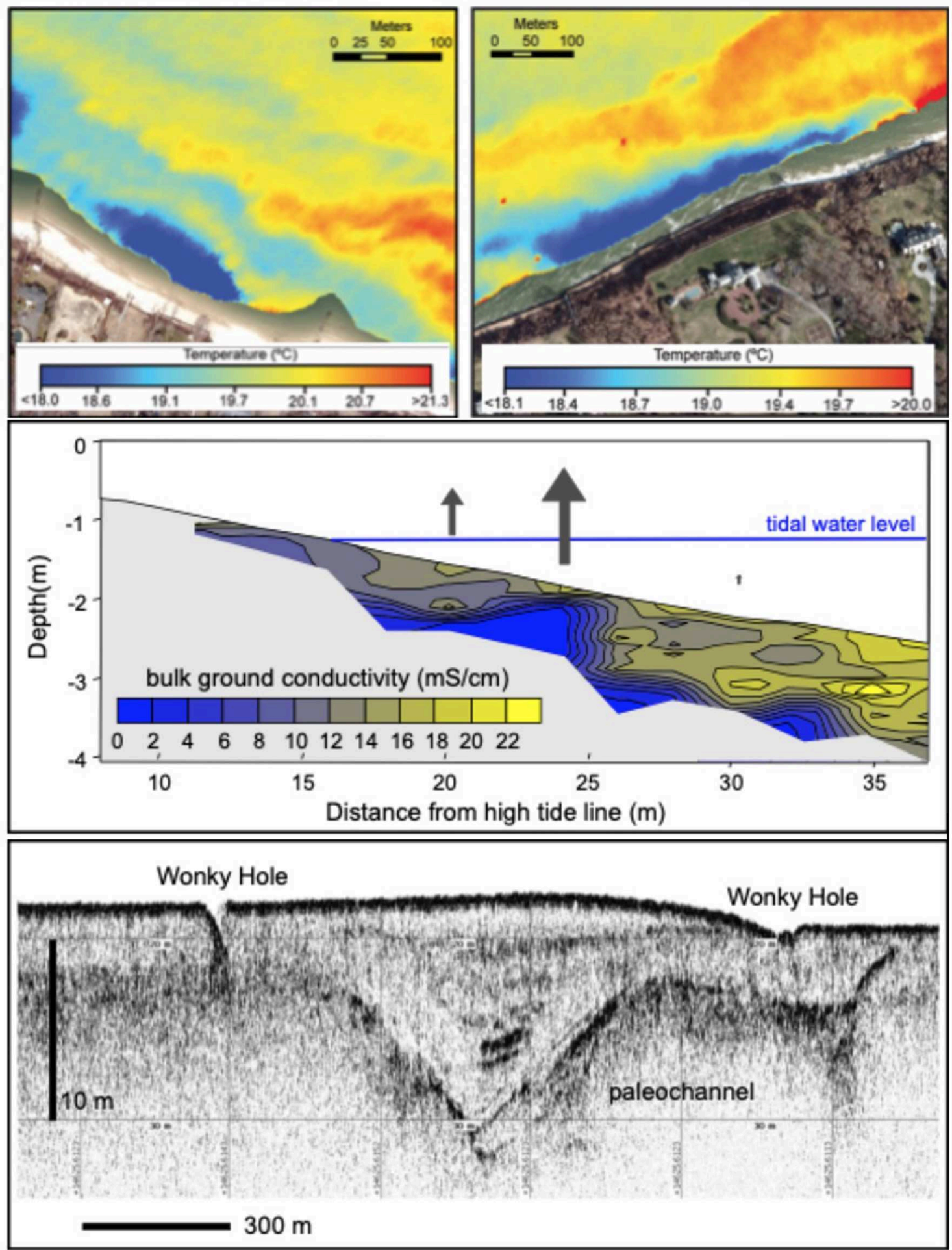

FIGURE 4 | (Top) Airborne Infrared maps from beaches on Long Island (USA) elucidating cold SGD plumes (adapted from Tamborski et al., 2015); (Center) bulk ground conductivity transect indicating preferential freshwater SGD flow path. Arrow length indicates SGD flow rates measured with seepage meters at the respective locations (adapted from Stieglitz et al., 2008a); (Bottom) Sub-bottom (seismic) profile of a riverine paleochannel and associated Wonky Holes (Great Barrier Reef, Australia) (Stieglitz, unpublished data). 
enriched in reduced species $\left[\mathrm{NH}_{4}^{+}, \mathrm{Fe}(\mathrm{II})\right.$, etc.]. Therefore, the STE has been found to be much more dynamic in terms of biogeochemical alterations, relative to river estuaries.

Amongst chemical species, the fluxes of nutrients via SGD have been studied most extensively since they have significant impacts on marine ecosystems. In a STE, the behavior of $\mathrm{N}$ species is very complicated depending on the redox conditions and organic matter re-mineralization. $\mathrm{NH}_{4}^{+}$is often found to be removed by nitrification in oxic conditions (Spiteri et al., 2008; Anwar et al., 2014; Anschutz et al., 2016) or also by adsorption onto particles (Buss et al., 2004; Lorah et al., 2009). Under anoxic conditions, dissolved $\mathrm{N}$ can also be removed by forming gaseous species (Kroeger and Charette, 2008; Couturier et al., 2017). Si and $\mathrm{P}$ in groundwater can be removed in STE by adsorption, but $\mathrm{P}$ can be potentially desorbed from the sediment surface layer under much higher Si concentrations since they compete for the same specific ligand sites including $\mathrm{Fe}$ - and $\mathrm{Mn}-$, and Al-oxides (Cho et al., 2019b). However, in organic-rich STEs, all these nutrients are highly enriched by re-mineralization. Recent studies also documented the importance of dissolved organic nitrogen (DON) and phosphorus (DOP) in delivering nutrients through SGD (Kim et al., 2013; Sadat-Noori et al., 2016; Stewart et al., 2018). Therefore, we can conclude that the impact of SGD is very different depending upon the hydrogeological and biogeochemical conditions of the STE.

There have been many upscaling attempts to gauge the magnitude of nutrients fluxes through SGD on basin scales. SGD-driven fluxes of nutrients are generally significant in coastal waters (Kim et al., 2005; Rodellas et al., 2015a; Cho et al., 2018). Recently the global volume of fresh submarine groundwater discharge (FSGD) has been estimated around 1\% of river discharge (Luijendijk et al., 2019; Zhou et al., 2019), less than the previously estimated 5-10\% (Oki and Kanae, 2006). Consequently, the global fluxes FSGD of DIN, DIP, and DSi through FSGD to the global ocean seem to be below $10 \%$ of those from river discharge (Cho et al., 2018 and references therein). However, Cho et al. (2018) showed that the fluxes of DIN, DIP, DSi through total (fresh+saline) groundwater discharge on a global scale were comparable to river inputs. Rahman et al. (2019) also showed a similar result for DSi input via saline SGD, accounting for a $25-30 \%$ increase in global estimates of net DSi inputs (riverine, SGD, aeolian, hydrothermal, and seafloor weathering) to the ocean.

SGD may also play an important role for the fluxes of terrestrial carbon to the ocean as a form of DOC or DIC. In addition, a significant amount of marine carbon is also returned back to the ocean by SGD. In general, marine vs. terrestrial sources of DOC and DIC are differentiated by stable carbon isotopes (Gramling et al., 2003). In a STE, DOC is transformed to DIC via microbial processes. DOC and DIC are also formed within a STE by the bacterial degradation of particulate organic carbon (POC). Therefore, many STEs show higher DOC concentrations in groundwater than coastal seawater, indicating that SGD is a potential DOC source to the near-shore ocean (Webb et al., 2019). However, the contribution of SGD to the marine DOC budget remains unknown relative to other sources such as in-situ production of DOC in the euphotic zone. Clearly, the importance of SGD on the fluxes of refractory and aged DOC to the ocean should be more extensively evaluated in the future.

Fluxes of DIC were found to be important in many oceanic regions. By considering SGD in the DIC budget in the ocean, the sink or source regions of $\mathrm{CO}_{2}$ have been re-evaluated (Cai et al., 2003; Dorsett et al., 2011; Liu et al., 2012). The importance of SGD-derived DIC fluxes to the oceans have been particularly emphasized in carbon-rich mangrove forest areas (Chen et al., 2018 b) and have been suggested to exceed regional river inputs in Florida (Liu et al., 2012) and in an Australian embayment (Stewart et al., 2015). In addition, DIC concentrations in STEs and their associated contributions to the ocean showed large seasonal variations (Wang et al., 2015). Fluorescent DOM (FDOM), especially humic-like varieties, is generally enriched in STEs, and thus SGD showed a significant influence on the coastal budget of humic-like FDOM (Kim et al., 2013; Suryaputra et al., 2015). Kim and Kim (2017) documented that fresh groundwater in Jeju Island, Korea, generally showed lower DOC due to degradation and higher humic-like FDOM produced from bacterial degradation of labile DOC and POC in aquifers. They suggested that SGD provides an environmental condition favorable for coral ecosystems by reducing UV penetration and DOC concentrations. Therefore, SGD-associated carbon studies should be conducted not only for establishing local/regional carbon budgets but also for understanding marine ecosystem changes and implications for ocean acidification.

Studies of trace element fluxes associated with SGD have shown that many elements exhibit non-conservative behavior within a STE. Although river estuaries are generally sinks of trace elements due to flocculation of particle reactive elements, STEs often display significantly higher trace element concentrations relative to river water or seawater in association with remineralization of organic matter, release from oxides, and desorption from sediments (Charette and Sholkovitz, 2006; Santos-Echeandia et al., 2009). Therefore, the behavior of trace elements in STEs is largely dependent on $\mathrm{pH}, \mathrm{Fe} / \mathrm{Mn}$ oxides, and bacterial activities. Due to such a reactive nature of trace elements to particles, colloids play an important role in the delivery of trace elements from STEs to the coastal ocean (Kim and Kim, 2015). In Jeju Island, Korea, Jeong et al. (2012) showed that the change $(\sim 20$-fold) in concentrations of trace elements (i.e., $\mathrm{Al}, \mathrm{Mn}, \mathrm{Fe}, \mathrm{Co}, \mathrm{Ni}$, and $\mathrm{Cu}$ ) in the STE resulted in the matching change in inventory of these elements in coastal waters. Although a STE can serve as a significant source for most trace elements which are extremely low in seawater, STEs can be an important sink of conservative elements in seawater by changing redox conditions. For example, forming reduced conditions for U uptake (Charette and Sholkovitz, 2006) and precipitation of Mn oxides for Mo adsorption (Beck et al., 2010). Although a few local or regional studies demonstrated the importance of SGD for the delivery of trace elements to the ocean (Moore, 2010; Jeong et al., 2012; Kim and Kim, 2015; Trezzi et al., 2016), so far the global or basin scale importance is largely unknown. It is particularly important for Fe since the growth of marine planktons could be limited by extremely low-level Fe in seawater, although it is a major element in the earth's crust. 
Thus, it is very important to look at the magnitude of SGDdriven dissolved trace elements to the ocean for basin-scale as well as local/regional scales in association with climate and ecosystem changes.

Among trace elements, rare earth elements (REE) associated with SGD have received considerable attention recently. In general, high enrichment of REE, relative to the simple binary mixing of meteoric groundwater and seawater has been observed in STEs, although the STE can also act as a sink for heavy REEs (HREE) owing to adsorption onto Fe oxides (Johannesson et al., 2011). In STEs, light REEs (LREE) are more readily exchangeable on aquifer mineral surfaces than HREEs, and HREEs and middle REEs (MREE) exhibit a greater association with oxide minerals (Willis and Johannesson, 2011; Chevis et al., 2015). Thus, redox conditions along the flow path of groundwater can affect REE concentration and fractionation (Johannesson et al., 2005, 2011; Tang and Johannesson, 2005, 2006). A case study carried out on a sandy STE in Florida (Chevis et al., 2015) showed that advection and bio-irrigation differentially affect REE fluxes to the ocean as fresh groundwater is enriched in HREEs, while marine pore-water is enriched in MREE in association with the reductive dissolution of $\mathrm{Fe}$ oxides/oxyhydroxides. Therefore, REE contributions to coastal waters are clearly identified due to large contributions of different REE patterns to coastal waters (Kim and Kim, 2011; Johannesson et al., 2017). Much more extensive studies are necessary to determine SGD's contribution to the budgets and fractionations of REE on basin and global scales.

The compilation of $\mathrm{Nd}$ isotopes in the global ocean showed that the traditionally believed main $\mathrm{Nd}$ sources, e.g., rivers and atmosphere, cannot explain the large difference in $\mathrm{Nd}$ isotope ratios and concentrations in different basins, the so called "Nd paradox." Recent studies showed that SGD can account for the missing $\mathrm{Nd}$ source ( $>90 \%$ of the known source; Tachikawa et al., 2003; Johannesson and Burdige, 2007; Chevis et al., 2015). However, much more local and regional evidence are necessary to validate this hypothesis. Besides, large enrichments of alkaline earth elements $(\mathrm{Sr}, \mathrm{Ba}$, and $\mathrm{Ra}$ and their isotopes) have been successfully utilized to trace SGD to the ocean. SGD inputs of Sr, with less radiogenic Sr than seawater, influence the $\mathrm{Sr}$ isotope budget in the ocean, making up $13-31 \%$ of the marine Sr isotope budget (Beck et al., 2013). This fluvial input is comparable in magnitude to the flux driven by submarine hydrothermal circulation through midocean ridges. Yet, the use of $\mathrm{Sr}$ isotopes as an SGD tracer is still challenging since $\mathrm{Sr}$ isotopic composition and distribution of the coastal waters are rather complicated (Huang et al., 2011). Such a complicated pattern seems to be associated with different isotopic ratios from different sources, fractionations along the path, and non-conservative behaviors within the STE (Andersson et al., 1994; Xu and Marcantonio, 2004; Huang and You, 2007). Since $\mathrm{Ra}$ isotopes are one of the more useful SGD tracers, more details concerning the $\mathrm{Ra}$ isotope applications for flux estimations will be covered in the following methodology section.

\section{Geochemical Methodology}

Coastal salinity may seem like an obvious SGD tracer but it has interferences from terrestrial surface runoff and it does not capture the recirculated seawater component of SGD. Therefore, since the 1990's several groundwater tracers have been applied for SGD quantification in addition to, or instead of salinity (Table 1). Among others, these include radium, radon, methane, silica, hydrogen, and oxygen stable isotopes of water (Bugna et al., 1996; Cable et al., 1996; Campbell and Bate, 1996; Moore, 1996; Godoy et al., 2013; Rocha et al., 2016). Radon and radium isotopes have been applied most frequently, with $40 \%$ of the published 473 SGD articles between 2015 and 2019 applying one or both (Web of Science, 2019). The advantage of radon $\left({ }^{222} \mathrm{Rn}, \mathrm{T}_{1 / 2}=3.8\right.$ days) is that automated measurement methods allow for easy time-series and spatial survey measurements. Due to the large concentration gradient between groundwater and ocean water, its gaseous nature, and relatively short half-life, radon is applicable for assessment of recent and local SGD inputs. Radium analysis of seawater, on the other hand, requires a collection of large volume samples and laboratory or shipboard measurements. However, its great advantage is that radium has four isotopes with half-lives covering a wide range of time scales $\left({ }^{224} \mathrm{Ra}, \mathrm{T}_{1 / 2}\right.$ $=3.6$ days; ${ }^{223} \mathrm{Ra}, \mathrm{T}_{1 / 2}=11.4$ days; ${ }^{228} \mathrm{Ra}, \mathrm{T}_{1 / 2}=5.7$ years; and ${ }^{226} \mathrm{Ra}, \mathrm{T}_{1 / 2}=1,600$ years) thus allowing SGD assessment on multiple spatial and temporal scales. In addition, radium isotopes can be used to estimate water mixing and residence times (Charette et al., 2008). For example, beyond the embayment scale, ocean-basin scale SGD estimates were recently performed using inventories of the relatively long-lived ${ }^{228} \mathrm{Ra}$ (Kwon et al., 2014). Uncertainties are often high for both radon and radium mass balance estimates, largely but not exclusively, because of the difficulty in constraining a value for the groundwater "endmember" (the concentration of the tracer in the discharging groundwater; Burnett et al., 2007; Schubert et al., 2019).

SGD tracer measurement methods have recently been improved to enhance detection limits and make more efficient measurements over longer time periods as well as obtaining finer spatial scale applications. One example of improvement for radium measurements is a large-volume (over 1,500 L/4 h) sampling method using commercially available in situ pumps modified to accept $\mathrm{MnO}_{2}$ coated filter cartridges (Henderson et al., 2013). The method has been applied on continental shelves as well as in open ocean environments and is a promising tool to significantly increase the number of observations of ocean basin-scale radium isotope inventories in the coming years. Improvement in the existing coastal radon detection methods via a commercially available radon-in-air detectors (RAD7, Durridge) was achieved by more efficient gas stripping via improved air-gas exchanger design (Santos et al., 2012a) and use of membrane extractors (Gilfedder et al., 2015). These allow for more powerful and efficient pumping and better radon measurement response rates during coastal surveys. The latter issue was also tackled by Petermann and Schubert (2015), who introduced a methodology to correct radon data collected using an air-water exchanger (RAD-Aqua, Durridge) connected to a RAD-7 radon detector for its response delay when moving 
TABLE 1 | Summary of the main geochemical tracers used in SGD related studies.

\begin{tabular}{|c|c|c|c|c|}
\hline Tracer & Measurement & Lab/in situ & Application & References \\
\hline Salinity & Conductivity & In situ & Fresh water SGD & \\
\hline${ }^{226} \mathrm{Ra}$ & Gamma-spec & Lab & SGD estimation & Moore, 1996 \\
\hline${ }^{222} \mathrm{Rn}$ & Lucas cells (alpha-scintillation) & $\mathrm{Lab}$ & SGD estimation & Cable et al., 1996 \\
\hline${ }^{222} \mathrm{Rn}$ & Automated (RAD-7, alpha-spectrometry) & In situ & $\begin{array}{l}\text { SGD estimation } \\
\text {-temporal -spatial }\end{array}$ & $\begin{array}{l}\text { Burnett et al., } 2001 ; \\
\text { Dulaiova et al., } 2005\end{array}$ \\
\hline${ }^{222} \mathrm{Rn}$ & Underwater gamma-spec (HPGe \& Nal) & In situ & $\begin{array}{l}\text { SGD estimation } \\
\text {-temporal -spatial }\end{array}$ & $\begin{array}{l}\text { Povinec et al., 2006; } \\
\text { Tsabaris et al., 2012; } \\
\text { Dulai et al., } 2016\end{array}$ \\
\hline${ }^{222} \mathrm{Rn}$ & Automated (RAD-7, alpha-spectrometry) & Lab, in situ & $\begin{array}{l}\text { STE residence time } \\
\text { estimation }\end{array}$ & $\begin{array}{l}\text { Goodridge and Melack, } \\
\text { 2014; Oh and Kim, } \\
2016\end{array}$ \\
\hline${ }^{220} \mathrm{Rn}$ & Automated (RAD-7, alpha-spectrometry) & In situ & $\begin{array}{l}\text { SGD prospecting } \\
\text { SGD estimation } \\
\text {-temporal -spatial }\end{array}$ & $\begin{array}{l}\text { Chanyotha et al., 2014, } \\
\text { 2018; Swarzenski } \\
\text { et al., } 2016\end{array}$ \\
\hline Methane & Gas chromatography & $\mathrm{Lab}$ & SGD estimation & Bugna et al., 1996 \\
\hline Methane & $\begin{array}{l}\text { METS membrane diffusion detector TETHYS in-situ } \\
\text { underwater mass spectrometry }\end{array}$ & In situ & $\begin{array}{l}\text { SGD estimation } \\
\text {-temporal -spatial }\end{array}$ & $\begin{array}{l}\text { Kim and Hwang, 2002; } \\
\text { Dulaiova et al., } 2010\end{array}$ \\
\hline${ }^{224} \mathrm{Ra},{ }^{223} \mathrm{Ra}$ & RaDeCC (alpha-scintillation) & $\mathrm{Lab}$ & $\begin{array}{l}\text { Water mass mixing, } \\
\text { residence times, SGD } \\
\text { estimation }\end{array}$ & $\begin{array}{l}\text { Moore and Arnold, } \\
\text { 1996; Charette et al., } \\
2008\end{array}$ \\
\hline${ }^{224} \mathrm{Ra} /{ }^{228} \mathrm{Th}$ & RaDeCC (alpha-scintillation) & Lab & Porewater exchange & Cai et al., 2014 \\
\hline${ }^{224} \mathrm{Ra},{ }^{223} \mathrm{Ra}$ & RaDeCC (alpha-scintillation) & Lab & Porewater exchange & Rodellas et al., 2015b \\
\hline${ }^{228} \mathrm{Ra}$ & Gamma-spectrometry & $\mathrm{Lab}$ & Ocean basin scale SGD & $\begin{array}{l}\text { Moore et al., 2008; } \\
\text { Kwon et al., } 2014\end{array}$ \\
\hline${ }^{226} \mathrm{Ra},{ }^{228} \mathrm{Ra}$ & Large volume pump + gamma spectrometry & Lab & Ocean basin scale SGD & Henderson et al., 2013 \\
\hline${ }^{224} \mathrm{Ra},{ }^{228} \mathrm{Ra}$ & Underwater gamma-spectrometry & In situ & $\begin{array}{l}\text { Residence times, SGD } \\
\text { estimation }\end{array}$ & Eleftheriou et al., 2017 \\
\hline fDOM, humification index & Fluorometry & $\mathrm{Lab}$ & SGD estimation & Nelson et al., 2015 \\
\hline Silica & Colorimetry & $\mathrm{Lab}$ & SGD estimation & Street et al., 2008 \\
\hline$\delta^{18} \mathrm{O}$ and $\delta^{2} \mathrm{H}$ & Optical spectroscopy & $\mathrm{Lab}$ & SGD estimation & $\begin{array}{l}\text { Godoy et al., 2013; } \\
\text { Rocha et al., } 2016\end{array}$ \\
\hline
\end{tabular}

between high and low radon activity water masses. Schubert et al. (2019) recently suggested additional improvements in the application of radon mass balance approaches that should improve corrections for radon losses from mixing and atmospheric evasion.

Since the "early days" of SGD studies, there has been a natural progression in improving radon measurement methodologies from labor-intensive grab samples collected in the field and analyzed in the lab or on ships (Mathieu et al., 1988), to the use of automated systems such as the RAD-AQUA (Burnett et al., 2001), to completely automated detection systems that can work unattended for months to years. Examples of the latter approach include autonomous water-proofed gammaspectrometry systems that are passive and do not require power-demanding water pumping (Tsabaris et al., 2012). A mobile underwater in-situ gamma-ray spectroscopy system was successfully applied for coastal surveys of radon and ${ }^{224} \mathrm{Ra}$ as a ship-deployed tow system (Patritis et al., 2018) and was also developed for long-term deployment on a permanently moored station where it recorded hourly radon measurements for multiple years (Dulai et al., 2016 and see Figure 5). These novel technologies bring the ability to perform longer and higher resolution SGD monitoring in diverse field settings, which will help document trends in SGD in different hydrogeologic and climatic settings, under extreme weather events, excessive groundwater pumping trends, and sea level rise scenarios. Eventually, such systems could be deployed as a global network.

There have been several new SGD tracers introduced recently. Another isotope of radon, ${ }^{220} \mathrm{Rn}$, also called "thoron," has been used for SGD prospecting, i.e., finding points of discharge as one must be close to a source to detect this very short-lived isotope. In an effort to employ ${ }^{220} \mathrm{Rn}$ as a groundwater tracer, Huxol et al. (2012) showed that while ${ }^{220} \mathrm{Rn}$ is easily detected in soil gas, it is often undetectable in groundwater. This is the case because under saturated conditions, migration of thoron through water is so slow that radioactive decay reduces the concentration to undetectable levels. However, flowing water apparently disturbs the immobile water layers stimulating the transfer of ${ }^{220} \mathrm{Rn}$ to the flowing water phase (Huxol et al., 2013). Thus, while thoron is difficult to detect in groundwater, it does serve as a good groundwater discharge tracer. Chanyotha et al. (2014) found intermittent thoron spikes in a $25-\mathrm{km}$ stretch of a Bangkok canal 


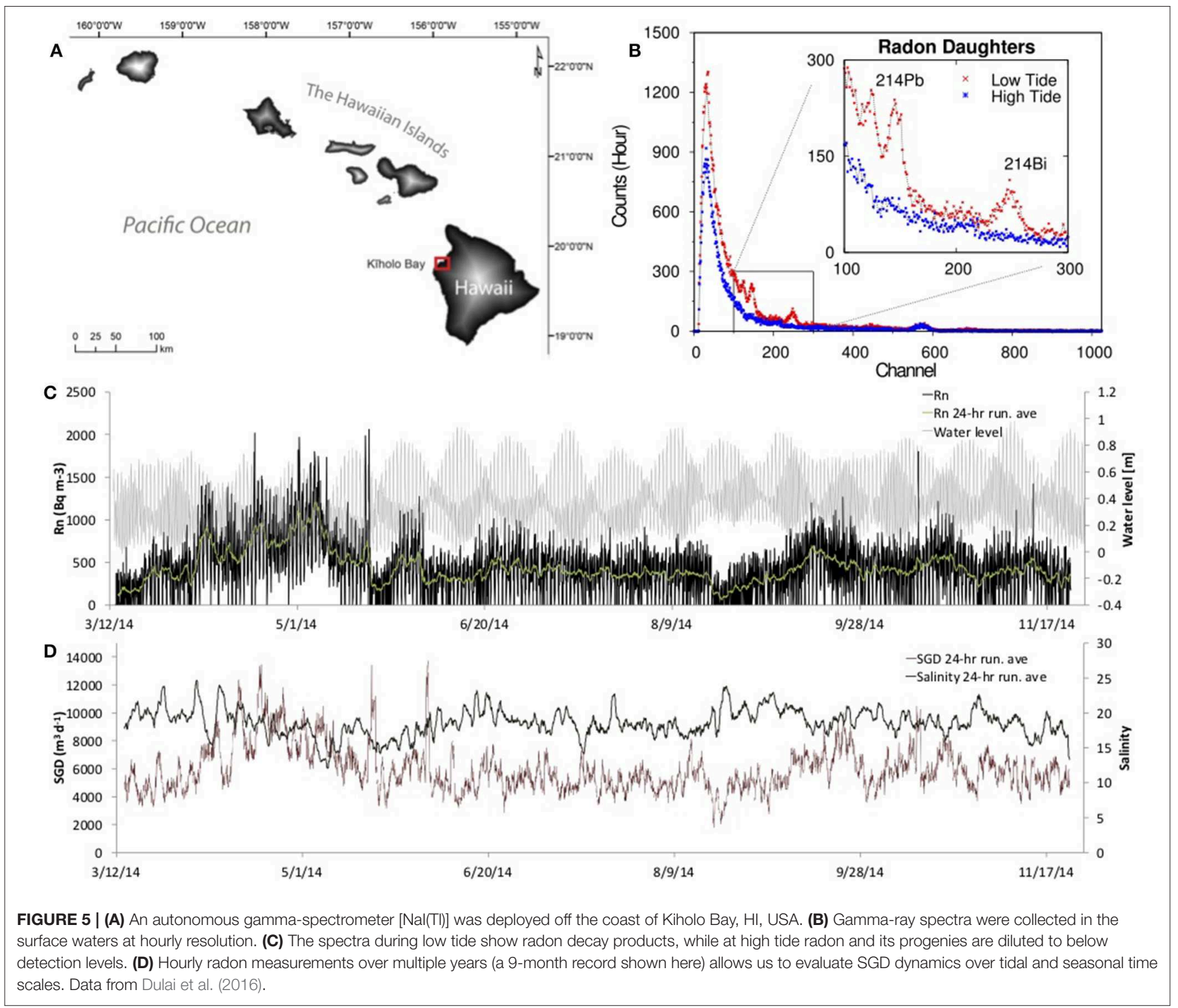

at essentially the same locations in surveys run along the same line 4 years apart. They also introduced a tool, the "meaningful thoron threshold," that ensures that a positive reading at or above the threshold has a $90 \%$ certainty of being a real detect. Thoron was also used in coastal spring discharge monitoring in Hawaii (Swarzenski et al., 2016).

Another natural SGD tracer involves dissolved organic matter (DOM). For example, SGD is often enriched in humic-like fluorescent DOM (Kim and Kim, 2017) and Nelson et al. (2015) demonstrated the utility of using indices of humidification derived from DOM in discharging groundwater as a tracer of SGD dispersal in nearshore waters.

There is renewed interest in the application of other U/Th series radionuclides, for example the ${ }^{224} \mathrm{Ra} /{ }^{228} \mathrm{Th}$ disequilibrium pair to study SGD and pore-water exchange dynamics (Cai et al., 2014). It has been demonstrated that carefully constructed radon and radium isotope mass-balances with well-defined end-members allow the quantification of and distinction between large-scale SGD and small-scale pore water exchange (Rodellas et al., 2015b; Cook et al., 2018). On a larger-scale form of exchange, radon has been applied to estimate beach pore water residence times and the flushing of a subterranean estuary, which showed positive correlation with tidal amplitudes and associated nutrient and dissolved organic carbon enrichment (Goodridge and Melack, 2014) and strong correlation with seawater intrusion (Oh and Kim, 2016). Radium and radon have also been combined with and used to document SGD-derived greenhouse gas fluxes in for example, a subtropical estuary (Sadat-Noori et al., 2016), the Amazon region (Call et al., 2019), and the Arctic (Lecher et al., 2015).

While geochemical tracers continue to provide valuable information for SGD studies, the most notable trend in the field is the application of multiple techniques that include geochemical tracers, geophysical approaches, direct 


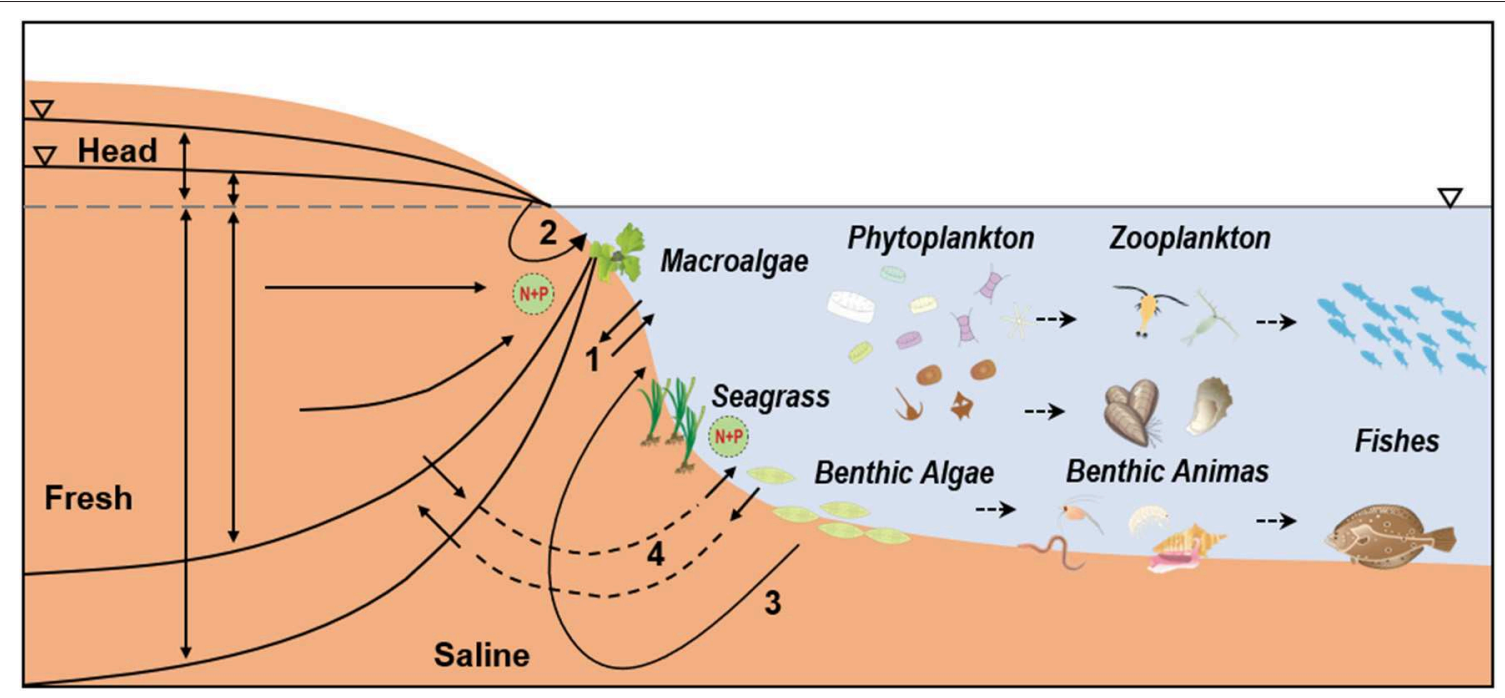

FIGURE 6 | Biological production in coastal ecosystems based on nutrients supplied through SGD. The numbers refer to the driving forces identified in Figure 2.

measurements, and hydrological modeling (e.g., Taniguchi et al., 2015). Such applications using multiple approaches decrease the degrees of freedom when interpreting SGD processes in often complex environments.

\section{BIO-ECOLOGICAL IMPACTS}

\section{Bio-ecological Processes}

Groundwater discharge has been recognized as a mechanism for transporting land-derived materials to the sea. Nutrients, carbon, metals, and other materials, which are dissolved in terrestrial groundwater, can drive bio-ecological processes in coastal seas. These effects are enhanced by recirculated seawater as it reacts within the aquifer sediment (see the Geochemical section). SGD can also act as a conduit of anthropogenic pollutants to coastal regions, and the lower salinity and $\mathrm{pH}$ associated with some types of SGD can stress local marine biota (reviewed in Lecher and Mackey, 2018).

Most studies of marine biota with respect to SGD focus on primary producers, because they provide the base of marine ecosystems as well as the chief response to nutrient supply via SGD (Figure 6). To date, many studies have revealed that nutrients transported through groundwater can support benthic and water column primary production in various coastal ecosystems. For example, SGD drives benthic primary production in the intertidal zone of the Yellow Sea (Waska and Kim, 2010, 2011). SGD also contributes significantly to reef productivity and/or calcification (Kamermans et al., 2002; Greenwood et al., 2013; McMahon and Santos, 2017). In a coastal water column, phytoplankton community structure was shown to be altered by SGD (Troccoli-Ghinaglia et al., 2010; Blanco et al., 2011; Adolf et al., 2019). More recently, a direct relationship between SGD and in situ phytoplankton primary productivity in nearshore coastal areas in Japan was found (Sugimoto et al., 2017). In Mediterranean coastal lagoons, Andrisoa et al. (2019) provided direct evidence for the role of karstic groundwater and porewater fluxes in sustaining primary production. Nutrient addition bioassay experiments support the view that SGD acts as a continual nutrient source (Gobler and Boneillo, 2003; Lecher et al., 2015).

Conversely, excess nutrient loadings via polluted groundwater into coastal seas may cause cultural eutrophication and microalgal blooms. In South Korea, SGD was identified as the most likely nutrient source triggering harmful algal blooms (HABs) and green tides (Hwang et al., 2005; Lee et al., 2009; Kwon et al., 2017; Cho et al., 2019a). In oligotrophic coastal reef environments, significant effects of SGD on marine biota were reported with their magnitudes varying according to landuse practices. The effects were shown to be most intense in locations with high anthropogenic impacts (Amato et al., 2016, 2018). Macroalgal overgrowths of coral reefs worldwide has been associated with nutrient inputs from SGD (Knee and Paytan, 2011). On the other hand, reef structure can also impact the nutrient load discharged into the sea by SGD (Oehler et al., 2019).

In the case of benthic communities, most SGD linkages are reported from intertidal regions. Several patterns have emerged from a limited number of studies suggesting that intertidal fresh SGD can change microbiological communities (Adyasari et al., 2019), determine species diversity, distribution, biomass distribution, and proliferation of benthic animals (e.g., Ouisse et al., 2011; Leitão et al., 2015; Foley, 2018). For example, benthic communities in the vicinity of freshwater SGD are often characterized by reduced species richness and diversity, due to high abundances of a small number of euryhaline/freshwatertolerant species (Zipperle and Reise, 2005; Dale and Miller, 2008). Intertidal SGD has been associated with a shift in dominant species of macrofauna and meiofauna and can exclude ubiquitous species that are in the surrounding marine environment (Zipperle and Reise, 2005; Welti et al., 2015; Shoji and Tominaga, 2018). SGD might also moderate pore-water 
temperatures and provide a refuge in sediment for macrofauna against extreme temperatures (Miller and Ullman, 2004). Overall, intertidal SGD may enhance biodiversity and species richness on a broader spatial scale.

SGD has been believed to contribute to coastal fisheries production including extensive aquaculture (e.g., oyster and mussel) in many locations around the world (Moosdorf and Oehler, 2017; Chen et al., 2018a; Shoji and Tominaga, 2018). Although there was little scientific evidence until recently, a growing body of interdisciplinary work is now demonstrating an ecological linkage between SGD and fisheries resources. For example, the Mediterranean mussel is a highly valuable commercial species. At the Olhos de Aqua beach in Portugal, groundwater inputs were recognized as increasing abundance and body size of these mussels (Piló et al., 2018). Cage experiments of the mussel Mytilus galloprovincialis in Salses-Leucate lagoon in France revealed that groundwater discharge provides favorable environmental conditions (i.e., higher temperature and food availability) for faster growth (Andrisoa et al., submitted). This is thought to be the case as groundwater discharge is a major source of nutrients and affects primary production within these ecosystems (Rodellas et al., 2015a; Andrisoa et al., 2019). Along the volcanic coast of northern Japan, fresh groundwater is an important factor providing suitable environment for phytoplankton that drives the high quality of the sessile bivalve Crasslstrea nippona, a commercially important local oyster (Hosono et al., 2012). In the Caribbean region, a groundwater-fed inlet provides a habitat for queen conch Lobatus gigas populations, which is one of the most important fishery resources in the region (Stieglitz and Dujon, 2017).

An increase of fish abundance and biomass and utilization of nursery areas has been observed in the vicinity of SGD (Hata et al., 2016; Utsunomiya et al., 2017; Starke et al., submitted; Yamane et al., 2019). The first location where an impact of SGD on fish abundance was directly recorded was in Obama Bay, Japan (Utsunomiya et al., 2017). There, the effect of nutrients transported via SGD on the food-chain was highlighted, because primary production was shown to be higher near SGD sites (Sugimoto et al., 2017). Furthermore, in the tidal flat of Seto Inland Sea, Japan, abundant juveniles of the marbles sole Pseudopleuronectes yokohamae were found near SGD sites with abundant prey organisms (Hata et al., 2016). Experimental evidence confirmed that the juvenile $P$. yokohamae obtained elevated levels of nutrition in the vicinity of SGD (Fujita et al., 2019). These findings demonstrated that SGD-derived nutrients enhanced marine fish production.

SGD has been shown to influence marine biota across a variety of coastal ecosystems. However, the mechanisms by which SGD affects primary production as well as marine animals differ from one ecosystem to another depending upon the hydrogeographical properties such as type of groundwater discharge (i.e., spring or seepage), location, species present, nutrient content of the groundwater, SGD flux, among other factors (Sugimoto et al., 2017; Shoji and Tominaga, 2018). Additional research is needed for a comprehensive assessment of SGD's impact on marine ecosystems.

\section{Bio-ecological Methodology}

Four-decades after Johannes's benchmark paper (Johannes, 1980), several SGD studies confirmed that groundwater is a significant source of nutrients to coastal seas. Although there is no doubt that SGD-derived nutrients contribute to marine organisms and ecosystem functions, evidence of the actual linkage between SGD and marine organisms is limited. Evidence seems best at some specific geological sites (e.g., karstic and volcanic regions) and intertidal sandflats where the discharge of groundwater can be directly viewed (Moosdorf and Oehler, 2017; Lecher and Mackey, 2018). In some cases, gas bubbles and excessive phenomena such as eutrophication and algal blooms are tied to SGD (Knee and Paytan, 2011). The difficulty in making the SGD-ecological linkage may be explained in two ways. First, marine organisms (i.e., microalgae, macroalgae, and animals) living in coastal waters or sediments are subject to various physical and biogeochemical processes that can affect their growth and physiology. In addition, nutrients supplied from multiple sources including rivers, atmospheric deposition, oceanic waters, and organic matter regeneration as well as groundwater inputs complicate an SGD assessment. Second, the pathway of SGD is invisible restricting our investigations in most coastal ecosystems. However, technological advances over the last decade have increased our ability to assess the ecological linkage to SGD in systems from local to shelf scales. Lecher and Mackey (2018) synthesized the effects of SGD on marine biota. Here we focus on how to assess the impact of SGD on marine organisms and ecosystems based on the latest methodological advances (Table 2).

Stable nitrogen isotope ratios $\left(\delta^{15} \mathrm{~N}\right)$ of primary producers are well-known to be useful in detecting the direct linkage between groundwater inputs and marine organisms when the dissolved inorganic nitrogen (DIN) of groundwater is isotopically distinct from other DIN sources. For example, McClelland and Valiela (1998) demonstrated a strong relationship between increases of $\delta^{15} \mathrm{~N}$ of $\mathrm{NO}_{3}^{-}$in groundwater and increases in $\delta^{15} \mathrm{~N}$ of various primary producers in several estuaries in Massachusetts. A clear positive relationship between seagrass $\delta^{15} \mathrm{~N}$ and the estimated groundwater flux was a pioneering work for this approach (Kamermans et al., 2002). To date, several studies have traced the behavior and fate of groundwater DIN using the $\delta^{15} \mathrm{~N}$ of primary producers, seagrasses, and macroalgae from local to regional scales (e.g., Lapointe et al., 2004, 2015; Derse et al., 2007; Honda et al., 2018; Andrisoa et al., 2019). In comparison to phytoplankton, macroalgae and seagrasses provide a timeintegrated view of the $\mathrm{N}$ sources. Given that macroalgae directly take up nutrients only from the water column whereas seagrass does so mainly from interstitial waters, macroalgae is considered the more appropriate tool to assess the long-term availability of nitrogen in the overlying water column (Umezawa et al., 2002). In recent studies, researchers have deployed pre-treated macroalgae to assess the time-integrated impacts of SGD on a fine spatial scale. For example, Amato et al. (2016) quantified a groundwater impacted area in Kahului Bay, Hawaii, using the $\delta^{15} \mathrm{~N}$ of both in situ macroalgae collected from intertidal and subtidal zones as well as pre-treated macroalga deployed for a short-term in anchored cages. Similar studies have been 
TABLE 2 | Summary of the main bio-ecological parameters used in SGD related studies.

\begin{tabular}{|c|c|c|c|c|}
\hline Tracers & Measurement & Lab/In situ & Application & References \\
\hline$\delta^{15} \mathrm{~N}$ and $\delta^{13} \mathrm{C}$ & Isotope ratio mass spectrometer (IRMS) & $\mathrm{Lab}$ & $\begin{array}{l}\text { Tracing nitrogen and } \\
\text { carbon flows, food web } \\
\text { analysis }\end{array}$ & $\begin{array}{l}\text { McClelland and Valiela, } \\
\text { 1998; Hata et al., 2016; } \\
\text { Andrisoa et al., } 2019\end{array}$ \\
\hline$\delta^{15} \mathrm{~N}$ of macroalgae deployed in the water & IRMS and macroalgae incubation & Lab + in situ & $\begin{array}{l}\text { Spatial mapping of } \\
\text { SGD impacts on } \\
\text { primary producers }\end{array}$ & Amato et al., 2016 \\
\hline Nutrient & Submersible colorimeter & In situ & $\begin{array}{l}\text { High resolution } \\
\text { monitoring of nutrient }\end{array}$ & Blanco et al., 2011 \\
\hline Nutrient & Spectrophotometry & Lab & $\begin{array}{l}\text { Primary production } \\
\text { estimation }\end{array}$ & $\begin{array}{l}\text { Waska and Kim, 2011; } \\
\text { Wang et al., } 2018\end{array}$ \\
\hline Chlorophyll & Fluorometry & Lab, in situ & $\begin{array}{l}\text { Biomass of } \\
\text { phytoplankton, }\end{array}$ & $\begin{array}{l}\text { Kobayashi et al., } 2017 \text {; } \\
\text { Honda et al., } 2018\end{array}$ \\
\hline Photosynthetic pigments & High performance liquid chromatography (HPLC) & Lab & $\begin{array}{l}\text { Class differentiation of } \\
\text { benthic algae }\end{array}$ & Waska and Kim, 2010 \\
\hline Phytoplankton & Spectral fluorometry & In situ & $\begin{array}{l}\text { Class differentiation of } \\
\text { phytoplankton }\end{array}$ & Blanco et al., 2011 \\
\hline Phytoplankton & Flow cytometer & $\mathrm{Lab}$ & $\begin{array}{l}\text { Size differentiation of } \\
\text { phytoplankton }\end{array}$ & $\begin{array}{l}\text { Lecher et al., 2015; } \\
\text { Adolf et al., } 2019\end{array}$ \\
\hline Phytoplankton & Bottle incubation with nutrient addition & Lab + in situ & $\begin{array}{l}\text { Growth rate of } \\
\text { phytoplankton, Limiting } \\
\text { nutrients }\end{array}$ & $\begin{array}{l}\text { Gobler and Boneillo, } \\
\text { 2003; Lecher et al., } \\
2015\end{array}$ \\
\hline Phytoplankton & Bottle incubation with enriched $\mathrm{DI}^{13} \mathrm{C}$ addition & Lab + in situ & $\begin{array}{l}\text { Primary productivity of } \\
\text { phytoplankton }\end{array}$ & Sugimoto et al., 2017 \\
\hline Dissolved oxygen & Optical oxygen sensor & In situ & $\begin{array}{l}\text { Net ecosystem } \\
\text { production, } \\
\text { photosynthesis, } \\
\text { respiration }\end{array}$ & Honda et al., 2018 \\
\hline $\mathrm{pCO}_{2}$ & Non-dispersive infrared sensor & In situ & $\begin{array}{l}\text { Net ecosystem } \\
\text { production, } \\
\text { photosynthesis, } \\
\text { respiration }\end{array}$ & $\begin{array}{l}\text { Santos et al., 2012a; } \\
\text { Maher et al., } 2019\end{array}$ \\
\hline Number of benthic animals & Core sampler & In situ & $\begin{array}{l}\text { Biomass and diversity } \\
\text { of animals, Habitat use }\end{array}$ & $\begin{array}{l}\text { Dale and Miller, 2008; } \\
\text { Leitão et al., } 2015\end{array}$ \\
\hline Number of fish & Net & In situ & $\begin{array}{l}\text { Biomass and diversity } \\
\text { of animals, Habitat use }\end{array}$ & $\begin{array}{l}\text { Hata et al., 2016; } \\
\text { Yamane et al., } 2019\end{array}$ \\
\hline Behavior of animals & Acoustic telemetry & In situ & Habitat use & $\begin{array}{l}\text { Stieglitz and Dujon, } \\
2017\end{array}$ \\
\hline Shell length of bivalve & Cage experiment & In situ & Growth rate & $\begin{array}{l}\text { (Andrisoa et al., } \\
\text { submitted) }\end{array}$ \\
\hline Total length of fish & Cage experiment & In situ & Growth rate & Fujita et al., 2019 \\
\hline
\end{tabular}

done at a fringing coral reef ecosystem of Hawai'i Island (Abaya et al., 2018) and four embayments in Tutuila, American Samoa (Shuler et al., 2019).

However, the exact relationship between algae and SGD is sometimes difficult to interpret because the isotopic composition of the source nitrogen is variable and can cause uncertainty when interpreting the isotope fractionation during the assimilation, especially if more than one form of nitrogen is present (e.g., $\mathrm{NO}_{3}^{-}$and $\mathrm{NH}_{4}^{+}$), or if more than one source of nitrogen is available (e.g., riverine, groundwater, oceanic, and regenerated nitrogen; Sugimoto et al., 2010, 2014). Thus, the utilization of the $\delta^{15} \mathrm{~N}$ of primary producers as a proxy for the $\delta^{15} \mathrm{~N}$ of nutrient sources is difficult unless adequate information is obtained regarding the $\delta^{15} \mathrm{~N}$ of the various sources. For example, in the Waquoit Bay estuarine system, a comparison of the $\delta^{15} \mathrm{~N}$ of phytoplankton, $\mathrm{NO}_{3}^{-}$, and $\mathrm{NH}_{4}^{+}$revealed that phytoplankton derived $3-47 \%$ of their $\mathrm{N}$ from groundwater $\mathrm{NO}_{3}^{-}$, while the major $\mathrm{N}$ source was regenerated $\mathrm{NH}_{4}^{+}$ (York et al., 2007).

Along with analyses of $\delta^{15} \mathrm{~N}$, gradients in the stable carbon isotope ratio $\left({ }^{13} \mathrm{C}\right)$ between fresh groundwater and marine end members (Gramling et al., 2003) can be utilized to detect the direct linkage between SGD and organisms. For example, the $\delta^{13} \mathrm{C}$ signature of macrophyte and phytoplankton in coastal lagoons on the French Mediterranean coastline shows the contribution of karstic groundwater discharge and porewater exchange as significant sources of dissolved inorganic carbon to primary production (Andrisoa et al., 2019). Therefore, these $\delta^{15} \mathrm{~N}$ and $\delta^{13} \mathrm{C}$ signals in primary producers can be traced through some marine food webs. Although there is still no clear evidence, 
Hata et al. (2016) suggest that there is a contribution of fresh SGD to local fish production on a tidal flat in Japan.

Biomass, abundance, productivity, physiology, and community structures of marine organisms have been directly assessed along natural gradients of SGD impact as well as compared at both SGD impacted and unimpacted sites. In contrast, visualization approaches using thermal infrared sensing and radon/radium tracing (see Geophysical and Geochemical sections) can be used as a guide for setting up ecological studies. Although the application of TIR imaging for ecological investigations has had limited applications thus far, Miller and Ullman (2004) and Grzelak et al. (2018) clarified a correspondence between the distributions of SGD and benthic organisms using thermal imaging. On the other hand, geochemical tracers such as radium and radon are often used for SGD-ecological studies. For example, Sugimoto et al. (2017) conducted field experiments at three Japanese coastal sites to elucidate the influence of SGD on in situ primary productivity of phytoplankton. Before the field experiments, they conducted continuous ${ }^{222} \mathrm{Rn}$ measurement surveys to visualize the spatial variability and gradient of SGD impacts. Consequently, they were able to report clear evidence for a direct association between SGD and coastal primary production. This visualization scheme has been applied in subsequent studies for marine organisms including fish (Utsunomiya et al., 2017). Furthermore, telemetry and biologging approaches for studying animal behavior associated with SGD will be helpful for future studies (Shoji et al., 2017; Stieglitz and Dujon, 2017).

When ${ }^{222} \mathrm{Rn}$ is used as a guide, simultaneous measurements of ${ }^{222} \mathrm{Rn}$ with other biological parameters enable us to assess the input of SGD and the response of marine organisms' activity. At a fringing coral reef in Japan, Blanco et al. (2011) conducted 4-days of continuous monitoring of ${ }^{222} \mathrm{Rn}$ activity, nitrate concentrations and class-differentiated phytoplankton using an automated radon analyzer and submersible sensors. Consequently, they revealed that groundwater-associated $\mathrm{NO}_{3}^{-}$ discharge drastically increased microalgal productivity and changed the community composition toward a dominance of a particular class. Furthermore, simultaneous measurements of ${ }^{222} \mathrm{Rn}$ with chlorophyll fluorescence, dissolved oxygen and $\mathrm{pCO}_{2}$ supported a direct linkage between SGD and primary production in time and space at various locations (Kobayashi et al., 2017; Honda et al., 2018; Maher et al., 2019).

Primary production can be estimated by using a nutrient budget method (Waska and Kim, 2011), although estimates of SGD flux and nutrient loading commonly reported in SGD studies may not be appropriate for use as a comparison of nutrient availability for marine biota. In an urbanized embayment in Hong Kong, primary productivity was estimated at $1.5-15 \times 10^{6} \mathrm{~g} \mathrm{C} \mathrm{d}^{-1}$, with $2-53 \%$ of the production being supported by SGD-driven $\mathrm{PO}_{4}^{3-}$ flux (Luo et al., 2014). In Daya Bay, China, $\sim 30 \%$ of total primary production was accounted for by SGD based on DIP budgets (Wang et al., 2018). This method can be easily scaled up from a local to a shelf scale. Luo et al. (2018) estimated that new production supported by groundwater-derived DIN constitutes up to about $24 \%$ of the total new production in a coastal upwelling shelf system.
Compared to primary producers, research for higher trophic species associated with SGD has just started. In the future, it is essential to clarify the spatial (e.g., local to global scales) and temporal (e.g., diel, seasonal, and decadal) variabilities in the processes relating to how SGD affects coastal fishery resources production. In particular, fish can move to and feed in multiple habitats within a relatively short temporal scale (e.g., tidal and daily scales). In focused flow ("submarine spring") situations, photo series can be used to interpret the behavior of fish at the local scale (Shoji and Tominaga, 2018; Starke et al., submitted). Combinations of hydrographic and geochemical surveys with bio-logging/telemetry approaches and stable isotope analyses together with fish movement and trophic flows in coastal ecosystems would enable accurate estimation of the contribution of SGD to fisheries production.

\section{ECONOMIC AND CULTURAL ASPECTS}

\section{Economic Aspects}

The presence of SGD in coastal zones, estuaries, and lagoons is associated with a variety of effects and uses, including geochemical and ecological dependencies (Johannes, 1980; Taniguchi et al., 2002; Burnett et al., 2003; Moore, 2010; Hosono et al., 2012), values associated with potable water for domestic use (Duarte et al., 2010; Pongkijvorasin et al., 2010; Burnett et al., 2017, 2018), as well as the historical and cultural importance of SGD-related submarine springs and plumes (Moosdorf and Oehler, 2017; Brosnan et al., 2018). The benefits associated with these uses can be expressed by a variety of metrics, including geochemical characteristics, aerial infrared maps of sea surface temperatures (Johnson et al., 2008), qualitative descriptions of cultural and historical significance (e.g., see next section), as well as economic evaluations of these SGD-related services and outcomes. Appropriate frameworks for deriving these economic estimates are the focus of this section.

Resource economics provides a theoretical framework for considering the economic value of SGD by directly linking groundwater and nearshore resources. Pongkijvorasin et al. (2010) developed a model of coastal groundwater management as a renewable resource and examined economically efficient management in the presence of known marine consequences of SGD. Concern for environmental conditions affecting marine biota controls the optimal steady-state head level of the aquifer. The model was discussed in general terms for any coastal groundwater resource where SGD has an impact on valuable nearshore resources. The authors then applied the model to a case study in Kona Hawai' $i$, where SGD is being actively studied and where both nearshore ecology and groundwater resources are significant sociopolitical issues. The application incorporated the economic value of SGD by including the market value of a freshwater-dependent marine algae directly in the model's objective function, thereby reducing the economically efficient trajectory of water consumption over time in order to support the growth of this economically and culturally important keystone species.

In a related case study in the same region by Duarte et al. (2010), the authors incorporated the consequences of water 
extraction on nearshore resources by imposing a minimum requirement on the growth rate of the valuable marine algae. Efficient pumping rates fluctuate according to various growth requirements on the algae and different assumptions regarding aquifer recharge rates. Given expected growth in future water demand, costly desalination would be required under baseline recharge conditions and a strict minimum standard, and under low recharge conditions regardless of minimum standards of growth. The authors calculated the net present value associated with each scenario (with varying algae growth rates and recharge rates). These values can then be compared, and the differences interpreted as representative of the tradeoff between increased groundwater pumping and the economic value of the nearshore species.

Other studies have taken a more simplified (and static) approach to assessing the economic benefit of groundwater and its related functions, including services by SGD. For example, Burnett et al. (2017) reported results from a choice-based survey and analysis suggesting that residents of Obama City Japan are willing to pay on average JPY 565 ( $\sim$ \$5 USD) per month to maintain the drinking water function and related ecological services of groundwater and SGD in the region. While these stated preference approaches assess values of groundwater and related functions more directly, they are potentially less useful for policy and management than those values derived from dynamic resource management frameworks that include trajectories of efficient resource use over time. In follow-up work in this region, Burnett et al. (2018) developed a model linking groundwater pumping in Obama City to the area's nearshore fishery resource. A decrease in SGD reduces the flow of nitrogen, phosphorus, silica and other nutrients into the ocean, which affects primary production and, ultimately, fishery production. While groundwater is currently being used for domestic use, the economically important nearshore fishery depends on freshwater SGD as a source of nutrients, while the SGD diminishes with increases in pumping. Using a 3D model (MODFLOW) of the groundwater aquifer and fishery catch, market price, and fishing cost data from Obama City, the authors monetized the impact of increased groundwater pumping on the nearshore marine fishery.

Changes in the structure of economies across the world influence the availability of SGD and associated benefits. Hugman et al. (2015) showed how increases in tourism and irrigated agriculture in Portugal influence the distribution of SGD along the coast as well as over time. External pressures on the groundwater aquifer will also affect the economic value associated with SGD. Changes in land use, climate, demand growth, and energy costs will affect future water extraction patterns over space and time, with resulting spatial and temporal implications for SGD and linked coastal and estuarine resources. In the context of the "coastal groundwater squeeze," Michael et al. (2017) describe potential impacts on coastal estuaries and coral reefs (see also Johannes, 1980; Valiela et al., 1990; Amato et al., 2016). Characterizing the linkages between these related systems (e.g., land use to aquifer to SGD to ecosystem) is the first step in developing appropriate frameworks to evaluate economic outcomes associated with adjustments within and between these compartments. As the science relating these interconnected systems improves, so will our ability to express the underlying economic values.

\section{Cultural Aspects}

Fresh groundwater flows into the ocean through focused conduits ("submarine springs"), can be visible to the eye and, in some cases, potable. Submarine springs have inspired humans since ancient times. Aside from having important geochemical, biological, and economic importance, sudden occurrences of fresher water in a salty ocean hold cultural, social, and spiritual relevance throughout the world as well.

The cultural relevance of submarine springs is welldocumented not only in the literature, but also through legends or places of worship and the naming of historical sites. The links are weakly documented by, for example, temple positions, as seen in Bangkok (Burnett et al., 2009) or on Lombok, Indonesia (Tanah Lot temple: Lubis and Bakti, 2013). Other indications of the cultural importance of submarine springs are place names related to water, such as Olhos de Aqua in Portugal (Carvalho et al., 2013) and local legends, such as the crying Tjilbruke spirit in South Australia (Isaacs, 1979). Because submarine springs are not usually the focus of people researching cultural heritage, little effort has been put into following these links in a structured way. In the following, the cultural relevance of SGD will be exemplified for two locations. This expands on a broader review of the societal use of SGD (Moosdorf and Oehler, 2017).

One of the most characteristic locations where submarine springs have been culturally important is the island of Bahrain. Submarine springs occur off the north side of the island and belong to a large aquifer system under the eastern part of the Arabian Peninsula (Rausch et al., 2014). Since Mesopotamian times ( $3000 \mathrm{BCE})$, literary texts mentioned the freshwater springs of the island (Crawford, 1998). This renders Bahrain as one of the prime candidates to be "Dilmun" (Bibby and Phillips, 1996; Crawford, 1998). In Sumeran tales, Dilmun is a paradise island where freshwater is plenty, and could possibly be related to the Christian Garden of Eden (Kramer, 1963). Later, in medieval times, the springs were used to refresh water supplies on sailing ships and during military conflicts (cf. Potts, 1985). Until the twentieth century, the water was also sold on land as drinking water (Williams, 1946). These springs, which have a 5000-year history of societal use, have been drying out due to increased onland pumping of groundwater in recent decades (Taniguchi et al., 2002; Rausch et al., 2014). The consequences of the lost heritage due to the lost springs, which may even have had an impact on the naming of the island (Faroughy, 1951) remains to be discussed.

On the other side of the planet, the first written accords from Rapa Nui (Easter Island) from the Eighteenth century report that the island provides very little freshwater (Martinsson-Wallin and Crockford, 2001). Precipitation infiltrates the permeable volcanic soils immediately and there are no perennial streams on the island (Brosnan et al., 2018). Members of an expedition by the British explorer Captain Cook note that natives drink seawater (Forster et al., 2000)—most likely this refers to them drinking from coastal springs (Brosnan et al., 2018). After the arrival of the Europeans, the native population quickly disappeared so that 
no accounts of the prehistoric water usage exist. But remnants of dug wells can be found only right at the coast, which, together with hydrogeological evidence point to fresh or brackish coastal seeps as a main drinking water source throughout the history of the island (Brosnan et al., 2018). While the cultural relevance of these drinking water sources is clear, it is also documented by the distribution of the famous stone monuments on the island, which occur more often close to the coastal seeps (DiNapoli et al., 2019). This leads to the hypothesis that the monuments marked important places, including coastal groundwater seeps (DiNapoli et al., 2019).

These examples showcase the social and historical importance of submarine springs to different cultures. Its relevance can sometimes also be used to qualitatively identify SGD locations, because locals, such as fishermen, often know the locations of submarine springs.

\section{SUMMARY AND REMAINING QUESTIONS}

We have updated the state of current research concerning SGD focusing on findings over the last decade, the "mature stage" (after the mid-2000s) of SGD research. Our treatment centered on the updates of measurement techniques, geophysical drivers, magnitudes, and effects.

In terms of measurement techniques, technological advances made during the developmental period of SGD research (mid1990s-mid-2000s) and continuing to this day have had a profound impact on recognizing the scope of SGD. While radon and radium isotopes remain as the most popular geochemical tracers, other possibilities are showing promise. The short-lived isotope of radon $\left({ }^{220} \mathrm{Rn}\right)$ can be used for locating sources of SGD. Advances in sub-sea gamma spectrometers allow unattended radon measurements on time scales up to years. In some circumstances DOM, FDOM, Si, and stable isotopes of $\mathrm{C}$ and $\mathrm{N}$ have proven valuable as SGD tracers. Macroalgae $\delta^{15} \mathrm{~N}$ can be used to assess the long-term time-integrated availability of $\mathrm{N}$ from SGD. Interpretations are sometimes difficult because of multiple forms and sources of N. Advances in geoelectric and TIR technologies now allows expanded access to these tools. While these geophysical approaches cannot necessarily measure SGD, they provide useful maps that improve field studies and can be used to document the temporal dynamics of SGD. Coupling geoelectric techniques with hydrological flow modeling should improve our understanding of complex mixing between saline and fresh water SGD. Telemetry and biologging approaches for studying animal behavior associated with SGD will be helpful in future studies.

While many researchers focus mainly on groundwater flow driven by a terrestrial head, SGD is influenced by many geophysical drivers. Many of these drivers (tidal pumping, wave setup, etc.) are marine in origin. SGD and porewater exchange are seen as different and overlapping processes. Other drivers (wave pumping, bioturbation, etc.) may produce flow that is considered SGD and/or porewater exchange depending upon the situation and measurement technique. When examined in time and space coordinates, one can differentiate SGD from pore water exchange. Multiple driving forces are not necessarily synergistic or additive and interact in a non-linear fashion. In addition, multiple time scales of overlapping drivers are difficult to study by field observations, so most investigations rely on numerical models.

Recent studies suggest that the magnitude of fresh SGD to the ocean is only $\sim 1 \%$ of the annual river discharge. Most previous estimates placed this figure in the $5-10 \%$ range. However, while the fresh SGD magnitude is small relative to river discharge, it may still have local impacts. Furthermore, the total (saline + fresh) SGD and its dissolved materials is many times greater than river inputs. While there has been a focus on high-porosity sandy environments in SGD studies, muddy wetlands and marshes can also be important. For example, tidally-driven porewater exchange in mangrove creeks around the world are sufficient to filter the entire continental shelf volume in $\sim 150$ years. Or, said another way, the mangrove creek flow is equivalent to about $1 / 3$ of the global annual river discharge. Muddy coasts thus deserve more attention.

The effects on delivery of nutrients and other dissolved materials to the coastal ocean can be profound but depends upon the hydrogeological and biogeochemical conditions of the STE in question. It has been shown in many cases that nutrients transported by SGD can support benthic and water column primary productivity as well as influence the phytoplankton community structure. Of course, an overabundance of nutrients from any source can lead to eutrophication and macroalgal blooms. Intertidal SGD can influence species diversity and biomass distribution of benthic communities. SGD effects on higher trophic levels, including fish, have been documented as well.

While groundwater discharge has traditionally been studied as a geophysical process, SGD is now recognized to have certain economic and cultural implications. In order to evaluate the economic value of SGD, one needs to develop a framework to make these estimations. For example, there is a need to characterize the linkages between these interconnected systems: aquifers-land use-SGD_ecosystems in order to evaluate economic outcomes as changes occur within these components. Cultural values come into play as well. Coastal food resources, often influenced by SGD, can have meaningful significance in various cultures. Thus, as SGD changes via groundwater pumping, climate change or other forces, the resource and the community dependent upon that resource are directly and indirectly affected.

Some remaining questions concerning SGD are listed below as suggestions for future research.

a) Spatial and temporal scale issues

For all the aspects considered here many spatial and temporal scale issues remain to be solved. While we recognize recirculated seawater as the main volumetric component of SGD, what are the time/length scales of the recharging process? How long are the residence times for water and dissolved material circulation in STEs?

b) Climate change impacts on SGD 
Predicting the impacts of climate change on SGD is a remaining challenge. Impacts on SGD by sea level rise and changes in precipitation and/or evapotranspiration need to be evaluated. Further collaborations with climate change researchers are essential.

c) Global estimations

While global estimations of SGD and dissolved nutrient inputs associated with SGD have been attempted, uncertainties remain. We can now say with some degree of certainty that fresh groundwater discharge contributes less than a few percent of riverine inputs and saline discharge is several folds higher than rivers. However, more precise evaluations still evade us. Global estimates of SGD-derived fluxes for key elements such as carbon and iron remain unavailable.

d) Muddy shorelines

Most SGD datasets were obtained from sandy shorelines. Muddy saltmarshes and mangroves are widespread along global coastlines but remain understudied. Their muddy soils are often permeable due to abundant animal burrows and can produce extremely high porewater concentrations of carbon and heavy metals. To develop global estimates of groundwater and porewater influences on marine biogeochemical cycles, a stronger focus on mangroves and saltmarshes may be required.

e) Sustainability

SGD is a relatively stable water discharge through a subterranean estuary into the coastal environment. Thus, the "stability" of SGD may be much different from river discharge and shape the environment in a number of ways. Improved

\section{REFERENCES}

Abaya, L. M., Wiegner, T. N., Beets, J. P., Colbert, S. L., Kaile’a, M. C., and Kramer, K. L. (2018). Spatial distribution of sewage pollution on a Hawaiian coral reef. Mar. Pollut. Bull. 130, 335-347. doi: 10.1016/j.marpolbul.2018.03.028

Adolf, J. E., Burns, J., Walker, J. K., and Gamiao, S. (2019). Near shore distributions of phytoplankton and bacteria in relation to submarine groundwater dischargefed fishponds, Kona coast, Hawai 'i, USA. Estuar. Coast. Shelf Sci. 219, 341-353. doi: 10.1016/j.ecss.2019.01.021

Adyasari, D., Hassenruck, C., Oehler, T., Sabdaningsih, A., and Moosdorf, N. (2019). Microbial community structure associated with submarine groundwater discharge in northern Java (Indonesia). Sci. Total Environ. 689, 590-601. doi: 10.1016/j.scitotenv.2019.06.193

Amato, D., Smith, C., and Duarte, T. (2018). Submarine groundwater discharge differentially modifies photosynthesis, growth, and morphology for two contrasting species of gracilaria (rhodophyta). Hydrology 5:65. doi: 10.3390/hydrology5040065

Amato, D. W., Bishop, J. M., Glenn, C. R., Dulai, H., and Smith, C. M. (2016). Impact of submarine groundwater discharge on marine water quality and reef biota of Maui. PLoS ONE 11:e0165825. doi: 10.1371/journal.pone.0165825

Andersson, P. S., Wasserburg, G., Ingri, J., and Stordal, M. C. (1994). Strontium, dissolved and particulate loads in fresh and brackish waters: the Baltic Sea and Mississippi Delta. Earth Planet. Sci. Lett. 124, 195-210. doi: 10.1016/0012-821X(94)00062-X

Andrisoa, A., Stieglitz, T. C., Rodellas, V., and Raimbault, P. (2019). Primary production in coastal lagoons supported by groundwater discharge and porewater fluxes inferred from nitrogen and carbon isotope signatures. Mar. Chem. 210, 48-60. doi: 10.1016/j.marchem.2019.03.003 understandings of ecosystem functions and linkages to SGD will clarify the corresponding impacts, helping improve management toward a more sustainable coastal environment.

SGD is now recognized as an important pathway between land and sea. In some cases, SGD may be the most important pathway. It has been shown here that SGD has a relationship to other parts of the coastal continuum, and it has relevance from many different points of view. The next steps are to further quantify the interconnected roles allowing one to predict impacts of SGD change within the coastal zone.

\section{AUTHOR CONTRIBUTIONS}

MT conceived and initiated this project, provided editing of all sections, and authored the Summary and Remaining Questions portion. HD authored the section on Geochemical Methodology. $\mathrm{KB}$ wrote the Economic Aspects section and contributed to editing throughout. IS authored Geophysical Processes. RS wrote the parts entitled Bio-ecological Processes and Bio-ecological Methodology. TS wrote the portion concerning Geophysical Methodology. GK wrote the section on Geochemical Processes. NM authored the Cultural Aspects section. WB wrote the Introduction, parts of the Summary and Remaining Questions and assisted with editing throughout.

\section{ACKNOWLEDGMENTS}

All co-authors acknowledge and thank the two reviewers, Henry Bokuniewicz (Stony Brook University) and Pei Xin (Hohai University) for their very constructive advice.

Anschutz, P., Charbonnier, C., Deborde, J., Deirmendjian, L., Poirier, D., Mouret, A., et al. (2016). Terrestrial groundwater and nutrient discharge along the 240-km-long Aquitanian coast. Mar. Chem. 185, 38-47. doi: 10.1016/j.marchem.2016.04.002

Anwar, N., Robinson, C., and Barry, D. A. (2014). Influence of tides and waves on the fate of nutrients in a nearshore aquifer: Numerical simulations. Adv. Water Resour. 73, 203-213. doi: 10.1016/j.advwatres.2014.08.015

Beck, A. J., Charette, M. A., Cochran, J. K., Gonneea, M. E., and PeuckerEhrenbrink, B. (2013). Dissolved strontium in the subterranean estuaryimplications for the marine strontium isotope budget. Geochim. Cosmochim. Acta 117, 33-52. doi: 10.1016/j.gca.2013.03.021

Beck, A. J., Cochran, J. K., and Sañudo-Wilhelmy, S. A. (2010). The distribution and speciation of dissolved trace metals in a shallow subterranean estuary. Mar. Chem. 121, 145-156. doi: 10.1016/j.marchem.2010.04.003

Bejannin, S., Van Beek, P., Stieglitz, T., Souhaut, M., and Tamborski, J. (2017). Combining airborne thermal infrared images and radium isotopes to study submarine groundwater discharge along the French Mediterranean coastline. J. Hydrol. 13, 72-90. doi: 10.1016/j.ejrh.2017.08.001

Bibby, G., and Phillips, C. (1996). Looking for Dilmun. Westminster: Stacey International.

Bighash, P., and Murgulet, D. (2015). Application of factor analysis and electrical resistivity to understand groundwater contributions to coastal embayments in semi-arid and hypersaline coastal settings. Sci. Total Environ. 532, 688-701. doi: 10.1016/j.scitotenv.2015.06.077

Blanco, A. C., Watanabe, A., Nadaoka, K., Motooka, S., Herrera, E. C., and Yamamoto, T. (2011). Estimation of nearshore groundwater discharge and its potential effects on a fringing coral reef. Mar. Pollut. Bull. 62, 770-785. doi: 10.1016/j.marpolbul.2011.01.005 
Bokuniewicz, H. (1980). Groundwater seepage into Great South Bay, New York. Estuar. Coast. Mar. Sci. 10, 437-444. doi: 10.1016/S0302-3524(80)80122-8

Bokuniewicz, H., Taniguchi, M., Ishitobi, T., Charrette, M., Allen, M., and Kontar, E. A. (2008). Direct measures of submarine groundwater discharge (SGD) over a fractured rock aquifer in Flamengo Bay Brazil. Estuar. Coast. Shelf Sci. 76, 466-472. doi: 10.1016/j.ecss.2007.07.047

Breier, J. A., Breier, C. F., and Edmonds, H. N. (2005). Detecting submarine groundwater discharge with synoptic surveys of sediment resistivity, radium, and salinity. Geophys. Res. Lett. 32:23. doi: 10.1029/2005GL024639

Brosnan, T., Becker, M. W., and Lipo, C. P. (2018). Coastal groundwater discharge and the ancient inhabitants of Rapa Nui (Easter Island), Chile. Hydrogeol. J. 27, 519-34. doi: 10.1007/s10040-018-1870-7

Buddemeier, R. W. (1996). "Groundwater flux to the ocean: definitions, data, applications, uncertainties," in Groundwater Discharge in the Coastal Zone, ed. R. W. Buddemeier (Texel; Moscow: LOICZ/Russian Academy of Sciences), 16-21.

Bugna, G., Chanton, J. P., Young, J. E., Burnett, W. C., and Cable, P. H. (1996). The importance of groundwater discharge to the methane budgets of nearshore and continental shelf waters of the northeastern Gulf of Mexico. Geochim. Cosmochim. Acta 60, 4735-4746. doi: 10.1016/S0016-7037(96)00290-6

Burnett, K., Wada, C. A., Endo, A., and Taniguchi, M. (2017). The economic value of groundwater in Obama. J. Hydrol. 11, 44-52. doi: 10.1016/j.ejrh.2015.10.002

Burnett, K., Wada, C. A., Taniguchi, M., Sugimoto, R., and Tahara, D. (2018). Evaluating the tradeoffs between groundwater pumping for snow-melting and nearshore fishery productivity in Obama city, Japan. Water 10:1556. doi: 10.3390/w10111556

Burnett, W. C., Aggarwal, P. K., Aureli, A., Bokuniewicz, H., Cable, J. E., Charette, M. A., et al. (2006). Quantifying submarine groundwater discharge in the coastal zone via multiple methods. Sci. Total Environ. 367, 498-543 doi: 10.1016/j.scitotenv.2006.05.009

Burnett, W. C., Bokuniewicz, H., Huettel, M., Moore, W. S., and Taniguchi, M. (2003). Groundwater and pore water inputs to the coastal zone. Biogeochemistry 66, 3-33. doi: 10.1023/B:BIOG.0000006066.21240.53

Burnett, W. C., Chanyotha, S., Wattayakorn, G., Taniguchi, M., Umezawa, Y., and Ishitobi, T. (2009). Underground sources of nutrient contamination to surface waters in Bangkok, Thailand. Sci. Total Environ. 407, 3198-3207. doi: 10.1016/j.scitotenv.2008.11.006

Burnett, W. C., Kim, G., and Lane-Smith, D. (2001). A continuous radon monitor for assessment of radon in coastal ocean waters. J. Radioanal. Nucl. Chem. 249, 167-172. doi: 10.1023/A:1013217821419

Burnett, W. C., Santos, I. R., Weinstein, Y., Swarzenski, P. W., and Herut, B. (2007). "Remaining uncertainties in the use of Rn-222 as a quantitative tracer of submarine groundwater discharge," in Proceedings of Symposium HS1001 at IUGG2007 International Association of Hydrological Sciences (IAHS) Publ. 312, A New Focus on Groundwater-Seawater Interactions (Perugia), 109-118.

Burrage, D. M., Heron, M. L., Hacker, J. M., Miller, J. L., Stieglitz, T. C., Steinberg, C. R., et al. (2003). Structure and influence of tropical river plumes in the Great Barrier Reef: application and performance of an airborne sea surface salinity mapping system. Remote Sens. Environ. 85, 204-220. doi: 10.1016/S0034-4257(02)00206-7

Buss, S. R., Herbert, A. W., Morgan, P., Thornton, S. F., and Smith, J. W. N. (2004). A review of ammonium attenuation in soil and groundwater. Q. J. Eng. Geol. Hydrogeol. 37, 347-359. doi: 10.1144/1470-9236/04-005

Cable, J. E., Burnett, W. C., Chanton, J. P., and Weatherly, G. (1996). Modeling groundwater flow into the ocean based on ${ }^{222} \mathrm{Rn}$. Earth Planet. Sci. Lett. 144, 591-604. doi: 10.1016/S0012-821X(96)00173-2

Cai, P., Shi, X., Moore, W. S., Peng, S., Wang, G., and Dai, M. (2014). 224Ra:228Th disequilibrium in coastal sediments: Implications for solute transfer across the sediment-water interface. Geochim. Cosmochim. Acta 125, 68-84. doi: 10.1016/j.gca.2013.09.029

Cai, W.-J., Wang, Y., Krest, J., and Moore, W. S. (2003). The geochemistry of dissolved inorganic carbon in a surficial groundwater aquifer in North Inlet, South Carolina, and the carbon fluxes to the coastal ocean. Geochim. Cosmochim. Acta 67, 631-639. doi: 10.1016/S0016-7037(02)01167-5

Call, M., Santos, I. R., Dittmar, T., De Rezende, C. E., Asp, N. E., and Maher, D. T. (2019). High pore-water derived $\mathrm{CO} 2$ and $\mathrm{CH} 4$ emissions from a macrotidal mangrove creek in the Amazon region. Geochim. Cosmochim. Acta 247, 106-120. doi: 10.1016/j.gca.2018.12.029
Campbell, E. E., and Bate, G. C. (1996). Groundwater as a possible controller of surf diatom biomass. Rev. Chil. Hist. Nat. 69, 503-510.

Carvalho, L. F., Rocha, C., Fleming, A., Veiga-Pires, C., and Anibal, J. (2013). Interception of nutrient rich submarine groundwater discharge seepage on European temperate beaches by the acoel flatworm, Symsagittifera roscoffensis. Mar. Pollut. Bull. 75, 150-156. doi: 10.1016/j.marpolbul.2013.07.045

Chanyotha, S., Kranrod, C., Burnett, W. C., Lane-Smith, D., and Simko, J. (2014). Prospecting for groundwater discharge in the canals of Bangkok via natural radon and thoron. J. Hydrol. 519, 1485-1492. doi: 10.1016/j.jhydrol.2014.09.014

Chanyotha, S., Sola, P., Kritsananuwat, R., Lane-Smith, D., and Burnett, W. C. (2018). Improved measurements of thoron $\left({ }^{220} \mathrm{Rn}\right)$ in natural waters. $J$. Radioanal. Nucl. Chem. 318, 777-784. doi: 10.1007/s10967-018-6110-z

Charette, M. A., Moore, W. S., and Burnett, W. C. (2008). "Uranium- and thorium-series nuclides as tracers of submarine groundwater discharge," in $U$ Th Series Nuclides in Aquatic Systems, eds S. Krishnaswami and J. Kirk Cochran (Amsterdam; Elsevier), 155-191. doi: 10.1016/S1569-4860(07)00005-8

Charette, M. A., and Sholkovitz, E. R. (2006). Trace element cycling in a subterranean estuary: Part 2. Geochemistry of the pore water. Geochim. Cosmochim. Acta 70, 811-826. doi: 10.1016/j.gca.2005.10.019

Chen, X., Lao, Y., Wang, J., Du, J., Liang, M., and Yang, B. (2018a). Submarine groundwater-borne nutrients in a tropical bay (Maowei Sea, China) and their impacts on the oyster aquaculture. Geochem. Geophys. Geosyst. 19, 932-951. doi: 10.1002/2017GC007330

Chen, X., Zhang, F., Lao, Y., Wang, X., Du, J., and Santos, I. R. (2018b). Submarine groundwater discharge-derived carbon fluxes in mangroves: an important component of blue carbon budgets? J. Geophys. Res. 123, 6962-6979. doi: 10.1029/2018JC014448

Chevis, D. A., Johannesson, K. H., Burdige, D. J., Cable, J. E., Martin, J. B., and Roy, M. (2015). Rare earth element cycling in a sandy subterranean estuary in Florida, USA. Mar. Chem. 176, 34-50. doi: 10.1016/j.marchem.2015.07.003

Cho, H. M., Kim, G., Kwon, E. Y., Moosdorf, N., Garcia-Orellana, J., and Santos, I. R. (2018). Radium tracing nutrient inputs through submarine groundwater discharge in the global ocean. Sci. Rep. 8:2439. doi: 10.1038/s41598-018-20806-2

Cho, H. M., Kim, G., and Shin, K. H. (2019a). Tracing nitrogen sources fueling coastal green tides off a volcanic island using radon and nitrogen isotopic tracers. Sci. Total Environ. 665, 913-919. doi: 10.1016/j.scitotenv.2019.02.212

Cho, H. M., Kim, J. H., and Kim, G. (2019b). Desorption of phosphate on sandy sediments by silicate in groundwater. Geochim. Cosmochim. Acta 257, 184-190. doi: 10.1016/j.gca.2019.05.003

Cook, P. G., Rodellas, V., and Stieglitz, T. C. (2018). Quantifying surface water, porewater, and groundwater interactions using tracers: tracer fluxes, water fluxes, and end-member concentrations. Water Resour. Res. 54, 2452-2465. doi: 10.1002/2017WR021780

Couturier, M., Tommi-Morin, G., Sirois, M., Rao, A., Nozais, C., and Chaillou, G. (2017). Nitrogen transformations along a shallow subterranean estuary. Biogeosciences 14, 3321-3336. doi: 10.5194/bg-14-3321-2017

Crawford, H. E. W. (1998). Dilmun and Its Gulf Neighbours. Cambridge: Cambridge University Press.

Cyronak, T., Santos, I. R., Erler, D. V., Maher, D. T., and Eyre, B. D. (2014). Drivers of $\mathrm{pCO}_{2}$ variability in two contrasting coral reef lagoons: the influence of submarine groundwater discharge. Global Biogeochem. Cycles 28, 398-414. doi: 10.1002/2013GB004598

Dale, R. K., and Miller, D. C. (2008). Hydrologic interactions of infaunal polychaetes and intertidal groundwater discharge. Mar. Ecol. Prog. Ser. 363 , 205-215. doi: 10.3354/meps07455

Derse, E., Knee, K. L., Wankel, S. D., Kendall, C., Berg, C. J., and Paytan, A. (2007). Identifying sources of nitrogen to Hanalei Bay, Kauai, utilizing the nitrogen isotope signature of macroalgae. Environ. Sci. Technol. 41, 5217-5223. doi: 10.1021/es0700449

Dimova, N. T., Swarzenski, P. W., Dulaiova, H., and Glenn, C. R. (2011). Utilizing multichannel electrical resistivity methods to examine the dynamics of the fresh water-seawater interface in two Hawaiian groundwater systems. J. Geophys. Res. 117:C02012. doi: 10.1029/2011JC007509

DiNapoli, R. J., Lipo, C. P., Brosnan, T., Hunt, T. L., Hixon, S., Morrison, A. E., et al. (2019). Rapa Nui (Easter Island) monument (ahu) locations explained by freshwater sources. PLoS ONE 14:e0210409. doi: 10.1371/journal.pone.02 10409 
Dorsett, A., Cherrier, J., Martin, J. B., and Cable, J. E. (2011). Assessing hydrologic and biogeochemical controls on pore-water dissolved inorganic carbon cycling in a subterranean estuary: a $14 \mathrm{C}$ and $13 \mathrm{C}$ mass balance approach. Mar. Chem. 127, 76-89. doi: 10.1016/j.marchem.2011.07.007

Duarte, T. K., Hemond, H. F., Frankel, D., and Frankel, S. (2006). Assessment of submarine groundwater discharge by handheld aerial infrared imagery: case study of Kaloko fishpond and bay, Hawai'i. Limnol. Oceanogr. 4, 227-236. doi: 10.4319/lom.2006.4.227

Duarte, T. K., Pongkijvorasin, S., Roumasset, J., Amato, D., and Burnett, K. (2010). Optimal management of a Hawaiian Coastal Aquifer with nearshore marine Ecological Interactions. Water Resour. Res. 46:W11545. doi: 10.1029/2010WR009094

Dulai, H., Kamenik, J., Waters, C. A., Kennedy, J., Babinec, J., Jolly, J., et al. (2016). Autonomous long-term gamma-spectrometric monitoring of submarine groundwater discharge trends in Hawaii. J. Radioanal. Nucl. Chem. 307, 1865-1870. doi: 10.1007/s10967-015-4580-9

Dulaiova, H., Camilli, R., Henderson, P. B., and Charette, M. A. (2010). Coupled radon, methane and nitrate sensors for large-scale assessment of groundwater discharge and non-point source pollution to coastal waters. J. Environ. Radioactiv. 101, 553-563. doi: 10.1016/j.jenvrad.2009.12.004

Dulaiova, H., Peterson, R., Burnett, W. C., and Lane-Smith, D. (2005). A multidetector continuous monitor for assessment of ${ }^{222} \mathrm{Rn}$ in the coastal ocean. J. Radioanal. Nucl. Chem. 263, 361-365. doi: 10.1007/s10967-005-0595-y

Eleftheriou, G., Tsabaris, C., Patiris, D. L., Androulakaki, E. G., and Vlastou, R. (2017). Estimation of coastal residence time of submarine groundwater discharge using radium progenies. Appl. Radiat. Isotopes 121, 44-50 doi: 10.1016/j.apradiso.2016.12.021

Evans, R. L., and Lizarralde, D. (2003). Geophysical evidence for karst formation associated with offshore groundwater transport: an example from North Carolina. Geochem. Geophys Geosyst. 4:8. doi: 10.1029/2003GC000510

Faroughy, A. (1951). The Bahrein Islands. New York, NY: Verry, Fisher \& Co., Inc.

Foley, L. J. (2018). Karst-channelled intertidal submarine groundwater discharge (SGD) conditions the form of the rock pool sessile assemblage. Estuar. Coast. Shelf Sci. 213, 236-244. doi: 10.1016/j.ecss.2018.08.014

Forster, G., Thomas, N., and Berghof, O. (2000). A Voyage Round the World. Honolulu, HI: University of Hawai'i Press.

Freeze, R. A., and Cherry, J. A. (1979). Groundwater. Englewood Cliffs, NJ: Prentice-Hall Inc.

Fujita, K., Shoji, J., Sugimoto, R., Nakajima, T., Honda, H., Takeuchi, M., et al. (2019). Increase in fish production through bottom-up trophic linkage in coastal waters induced by nutrients supplied via submarine groundwater. Front. Environ. Sci. 7:82. doi: 10.3389/fenvs.2019.00082

Geng, X., and Boufadel, M. C. (2017). The influence of evaporation and rainfall on supratidal groundwater dynamics and salinity structure in a sandy beach. Water Resour. Res. 53, 6218-6238. doi: 10.1002/2016WR020344

Gilfedder, B. S., Frei, S., Hofmann, H., and Cartwright, I. (2015). Groundwater discharge to wetlands driven by storm and flood events: Quantification using continuous Radon-222 and electrical conductivity measurements and dynamic mass-balance modelling. Geochim. Cosmochim. Acta 165, 161-177. doi: 10.1016/j.gca.2015.05.037

Gobler, C. J., and Boneillo, G. E. (2003). Impacts of anthropogenically influenced groundwater seepage on water chemistry and phytoplankton dynamics within a coastal marine system. Mar. Ecol. Prog. Ser. 255, 101-114. doi: $10.3354 /$ meps 255101

Godoy, J. M., Souza, T. A., Godoy, M. L. D. P., Moreira, I., Carvalho, Z. L., Lacerda, L. D., et al. (2013). Groundwater and surface water quality in a coastal bay with negligible fresh groundwater discharge: Arraial do Cabo, Brazil. Mar. Chem. 156, 85-97. doi: 10.1016/j.marchem.2013.05.004

Goodridge, B. M., and Melack, J. M. (2014). Temporal evolution and variability of dissolved inorganic nitrogen in beach pore water revealed using radon residence times. Environ. Sci. Technol. 48, 14211-14218. doi: 10.1021/es504017j

Gramling, C., McCorkle, D., Mulligan, A., and Woods, T. J. L. (2003). A carbon isotope method to quantify groundwater discharge at the land-sea interface. Limnol. Oceanogr. 48, 957-970. doi: 10.4319/lo.2003.48.3.0957

Greenwood, J. E., Symonds, G., Zhong, L., and Lourey, M. (2013). Evidence of submarine groundwater nutrient supply to an oligotrophic barrier reef. Limnol. Oceanogr. 58, 1834-1842. doi: 10.4319/lo.2013.58.5.1834
Greskowiak, J. (2014). Tide-induced salt-fingering flow during submarine groundwater discharge. Geophys. Res. Lett. 41, 6413-6419. doi: 10.1002/2014GL061184

Grzelak, K., Tamborski, J., Kotwicki, L., and Bokuniewicz, H. (2018). Ecostructuring of marine nematode communities by submarine groundwater discharge. Mar. Environ. Res. 136, 106-119. doi: 10.1016/ j.marenvres.2018.01.013

Gustafson, C., Key, K., and Evans, R. L. (2019). Aquifer systems extending far offshore on the U.S. Atlantic margin. Sci. Rep. 9:8709. doi: 10.1038/s41598-019-44611-7

Hata, M., Sugimoto, R., Hori, M., Tomiyama, T., and Shoji, J. (2016). Occurrence, distribution and prey items of juvenile marbled sole Pseudopleuronectes yokohamae around a submarine groundwater seepage on a tidal flat in southwestern Japan. J. Sea Res. 111, 47-53. doi: 10.1016/j.seares.2016. 01.009

Henderson, P. B., Morris, P. J., Moore, W. S., and Charette, M. A. (2013). Methodological advances for measuring low level radium isotopes in seawater. J. Radioanal. Nucl. Chem. 296, 357-362. doi: 10.1007/s10967-012-2047-9

Henderson, R. D., Day-Lewis, F. D., Abarca, E., Harvey, C. F., Karam, H. N., Liu, L., et al. (2009). Marine electrical resistivity imaging of submarine groundwater discharge: Sensitivity analysis and application in Waquoit Bay, Massachusetts, USA. Hydrogeol. J. 18, 173-185. doi: 10.1007/s10040-009-0498-Z

Honda, H., Sugimoto, R., Kobayahsi, S. (2018). "Submarine groundwater discharge and its influence on primary production in Japanese coasts: Case study in Obama Bay," in The Water-Energy-Food Nexus. Human-Environmental Security in the Asia-Pacific Ring of Fire, eds A. Endo and T. Oh (Singapore: Springer), 101-115.

Hosono, T., Ono, M., Burnett, W. C., Tokunaga, T., Taniguchi, M., and Akimichi, T. (2012). Spatial distribution of submarine groundwater discharge and associated nutrients within a local coastal area. Environ. Sci. Technol. 46, 5319-5326. doi: 10.1021/es2043867

Huang, K. F., and You, C. F. (2007). Tracing freshwater plume migration in the estuary after a typhoon event using Sr isotopic ratios. Geophys. Res. Lett. 34, 2403-2408. doi: 10.1029/2006GL028253

Huang, K. F., You, C. F., Chung, C. H., and Lin, I. T. (2011). Nonhomogeneous seawater Sr isotopic composition in the coastal oceans: a novel tool for tracing water masses and submarine groundwater discharge. Geochem. Geophys. Geosyst. 12:3372. doi: 10.1029/2010GC003372

Huettel, M., Berg, P., and Kostka, J. E. (2014). Benthic exchange and biogeochemical cycling in permeable sediments. Annu. Rev. Mar. Sci. 6, 23-51. doi: 10.1146/annurev-marine-051413-012706

Huettel, M., and Webster, I. T. (2000). "Porewater flow in permeable sediments." in Benthic Boundary Layer: Transport Processes and Biochemistry, eds B. P. Boudreau and B. B. Jørgensen (Oxford: Oxford Press), 144-179.

Hugman, R., Stigter, T. Y., Monteiro, J. P., Costa, L., and Nunes, L. M. (2015). Modeling the spatial and temporal distribution of coastal groundwater discharge for different water use scenarios under epistemic uncertainty: case study in South Portugal. Environ. Earth Sci. 73, 2657-2669. doi: 10.1007/s12665-014-3709-4

Huxol, S., Brennwald, M. S., Hoehn, E., and Kipfer, R. (2012). On the fate of ${ }^{220} \mathrm{Rn}$ in soil material in dependence of water content: implications from field and laboratory experiments. Chem. Geol. 298-299, 116-122. doi: 10.1016/j.chemgeo.2012.01.002

Huxol, S., Brennwald, M. S., and Kipfer, R. (2013). Processes controlling ${ }^{220} \mathrm{Rn}$ concentrations in the gas and water phases of porous media. Chem. Geol. 335, 87-92. doi: 10.1016/j.chemgeo.2012.10.049

Hwang, D. W., Lee, Y. W., and Kim, G. (2005). Large submarine groundwater discharge and benthic eutrophication in Bangdu Bay on volcanic Jeju Island, Korea. Limnol. Oceanogr. 50, 1393-1403. doi: 10.4319/lo.2005.50.5.1393

Isaacs, J. (1979). Australian Dreaming: 40,000 Years of Aboriginal History. Sydney, NSW; New York, NY: Lansdowne Press.

Jeong, J., Kim, G., and Han, S. (2012). Influence of trace element fluxes from submarine groundwater discharge (SGD) on their inventories in coastal waters off volcanic island, Jeju, Korea. Appl. Geochem. 27, 37-43. doi: 10.1016/j.apgeochem.2011.08.014

Johannes, R. E. (1980). The ecological significance of the submarine discharge of groundwater. Mar. Ecol. Prog. Ser. 3, 365-373. doi: 10.3354/meps003365 
Johannesson, K. H., and Burdige, D. J. (2007). Balancing the global oceanic neodymium budget: evaluating the role of groundwater. Earth Planet. Sci. Lett. 253, 129-142. doi: 10.1016/j.epsl.2006.10.021

Johannesson, K. H., Chevis, D. A., Burdige, D. J., Cable, J. E., Martin, J. B., and Roy, M. (2011). Submarine groundwater discharge is an important net source of light and middle REEs to coastal waters of the Indian River Lagoon, Florida, USA. Geochim. Cosmochim. Acta 75, 825-843. doi: 10.1016/j.gca.2010.11.005

Johannesson, K. H., Cortés, A., Ramos Leal, J. A., Ramírez, A. G., and Durazo, J. (2005). "Geochemistry of rare earth elements in groundwaters from a Rhyolite Aquifer, Central México," in Rare Earth Elements in Groundwater Flow Systems. Water Science and Technology Library, Vol. 51, ed K. H. Johannesson (Dordrecht: Springer), 188-222.

Johannesson, K. H., Palmore, C. D., Fackrell, J., Prouty, N. G., Swarzenski, P. W., Chevis, D. A., et al. (2017). Rare earth element behavior during groundwaterseawater mixing along the Kona Coast of Hawaii. Geochim. Cosmochim. Acta 198, 229-258. doi: 10.1016/j.gca.2016.11.009

Johnson, A. G., Glenn, C. R., Burnett, W. C., Peterson, R. N., and Lucey, P. G. (2008). Aerial infrared imaging reveals large nutrient-rich groundwater inputs to the ocean. Geophys. Res. Lett. 35:L15606. doi: 10.1029/2008GL034574

Johnson, C. D., Swarzenski, P. W., Richardson, C. M., Smith, C. G., Kroeger, K. D., and Ganguli, P. M. (2015). Ground-truthing electrical resistivity methods in support of submarine groundwater discharge studies: examples from Hawaii, Washington, and California. J. Environ. Eng. Geophys. 20, 81-87. doi: 10.2113/JEEG20.1.81

Joly, J. (1899). An Estimate of the Geological Age of the Earth. Dublin: Scientific Transactions of the Royal Dublin Society.

Kamermans, P., Hemminga, M. A., Tack, J. F., Mateo, M. A., Marb,à, N., and Mtolera, M. (2002). Groundwater effects on diversity and abundance of lagoonal seagrasses in Kenya and on Zanzibar Island (East Africa). Mar. Ecol. Prog. Ser. 231, 75-83. doi: 10.3354/meps 231075

Kelly, J. L., Glenn, C. R., and Lucey, P. G. (2013). High-resolution aerial infrared mapping of groundwater discharge to the coastal ocean. Limnol. Oceanogr. 11, 262-277. doi: 10.4319/lom.2013.11.262

Kim, G., Hwang, D.-W. (2002). Tidal pumping of groundwater into the coastal ocean revealed from submarine 222Rn and $\mathrm{CH} 4$ monitoring. Geophys. Res. Lett. 29, 23-27. doi: 10.1029/2002GL015093

Kim, G., Ryu, J. W., Yang, H. S., and Yun, S. T. (2005). Submarine groundwater discharge (SGD) into the Yellow Sea revealed by 228Ra and 226Ra isotopes: Implications for global silicate fluxes. Earth Planet. Sci. Lett. 237, 156-166. doi: 10.1016/j.epsl.2005.06.011

Kim, I., and Kim, G. (2011). Large fluxes of rare earth elements through submarine groundwater discharge (SGD) from a volcanic island, Jeju, Korea. Mar. Chem. 127, 12-19. doi: 10.1016/j.marchem.2011.07.006

Kim, I., and Kim, G. (2015). Role of colloids in the discharge of trace elements and rare earth elements from coastal groundwater to the ocean. Mar. Chem. 176, 126-132. doi: 10.1016/j.marchem.2015.08.009

Kim, J., and Kim, G. (2017). Inputs of humic fluorescent dissolved organic matter via submarine groundwater discharge to coastal waters off a volcanic island (Jeju, Korea). Sci. Rep. 7:7921. doi: 10.1038/s41598-017-08518-5

Kim, T. H., Kwon, E., Kim, I., Lee, S. A., and Kim, G. (2013). Dissolved organic matter in the subterranean estuary of a volcanic island, Jeju: importance of dissolved organic nitrogen fluxes to the ocean. J. Sea Res. 78, 18-24. doi: 10.1016/j.seares.2012.12.009

King, J. N. (2012). Synthesis of benthic flux components in the Patos Lagoon coastal zone, Rio Grande do Sul, Brazil. Water Resour. Res. 48:W12530. doi: 10.1029/2011WR011477

Knee, K., and Paytan, A. (2011). 4.08 submarine groundwater discharge: a source of nutrients, metals, and pollutants to the Coastal Ocean. Treat. Estuar. Coast. Sci. 4, 205-234. doi: 10.1016/B978-0-12-374711-2.00410-1

Kobayashi, S., Sugimoto, R., Honda, H., Miyata, Y., Tahara, D., Tominaga, O., et al. (2017). High-resolution mapping and time-series measurements of $222 \mathrm{Rn}$ concentrations and biogeochemical properties related to submarine groundwater discharge along the coast of Obama Bay, a semi-enclosed sea in Japan. Prog. Earth Planet. Sci. 4:6. doi: 10.1186/s40645-017-0124-y

Kohout, F. A. (1966). Submarine springs: a neglected phenomenon of coastal hydrology. Hydrology 26, 391-413.

Kolokoussis, P., Karathanassi, V., Rokos, D., Argialas, D., Karageorgis, A. P., and Georgopoulos, D. (2011). Integrating thermal and hyperspectral remote sensing for the detection of coastal springs and submarine groundwater discharges. Int. J. Remote Sens. 32, 8231-8251. doi: 10.1080/01431161.2010.533209

Kramer, S. N. (1963). The Sumerians: Their History, Culture, and Character. Chicago, IL: University of Chicago Press.

Kroeger, K. D., and Charette, M. A. (2008). Nitrogen biogeochemistry of submarine groundwater discharge. Limnol. Oceanogr. 53, 1025-1039. doi: 10.4319/lo.2008.53.3.1025

Krupa, S. L., Belanger, T. V., Heck, H. H., Brok, J. T., and Jones, B. J. (1998). Krupaseep - the next generation seepage meter. J. Coast Res. 25, 210-213.

Kwon, E. Y., Kim, G., Primeau, F., Moore, W. S., Cho, H-M, DeVries, T., et al. (2014). Global estimate of submarine groundwater discharge based on an observationally constrained radium isotope model. Geophys. Res. Lett. 42, 8438-8444. doi: 10.1002/2014GL061574

Kwon, H. K., Kang, H., Oh, Y. H., Park, S. R., and Kim, G. (2017). Green tide development associated with submarine groundwater discharge in a coastal harbor, Jeju, Korea. Sci Rep. 7:6325. doi: 10.1038/s41598-01706711-0

Lapointe, B. E., Barile, P. J., and Matzie, W. R. (2004). Anthropogenic nutrient enrichment of seagrass and coral reef communities in the Lower Florida Keys: discrimination of local versus regional nitrogen sources. J. Exp. Mar. Biol. Ecol. 308, 23-58. doi: 10.1016/j.jembe.2004.01.019

Lapointe, B. E., Herren, L. W., Debortoli, D. D., and Vogel, M. A. (2015). Evidence of sewage-driven eutrophication and harmful algal blooms in Florida's Indian River Lagoon. Harmful Algae 43, 82-102. doi: 10.1016/j.hal.2015.01.004

Lecher, A., and Mackey, K. (2018). Synthesizing the effects of submarine groundwater discharge on Marine Biota. Hydrology 5:60. doi: 10.3390/hydrology5040060

Lecher, A. L., Kessler, J. D., Sparrow, K. J., Kodovska, F. G.-T., Dimova, N., Murry, J., et al. (2015). Methane transport through submarine groundwater discharge to the North Pacific and Arctic Ocean at two Alaskan sites. Limnol. Oceanogr. 61, S344-55. doi: 10.1002/lno.10118

Lee, D. R. (1977). A device for measuring seepage flux in lakes and estuaries. Limnol. Oceanogr. 22, 140-147. doi: 10.4319/lo.1977.22.1.0140

Lee, E., Kang, K. M., Hyun, S. P., Lee, K. Y., Yoon, H., Ha, K., et al. (2016a). Submarine groundwater discharge revealed by aerial thermal infrared imagery: a case study on Jeju Island, Korea. Hydrol. Process. 30, 3494-3506. doi: 10.1002/hyp.10868

Lee, E., Yoon, H., Hyun, S. P., Burnett, W. C., Koh, D. C., Kang, K. M., et al. (2016b). Unmanned aerial vehicles (UAVs)-based thermal infrared (TIR) mapping, a novel approach to assess groundwater discharge into the coastal zone. Limnol. Oceanogr. 14, 725-735. doi: 10.1002/lom 3.10132

Lee, J., and Kim, G. (2015). Dependence of $\mathrm{pH}$ in coastal waters on the adsorption of protons onto sediment minerals. Limnol. Oceanogr. 60, 831-839. doi: 10.1002/lno.10057

Lee, Y. W., Hwang, D. W., Kim, G., Lee, W. C., and Oh, H. T. (2009). Nutrient inputs from submarine groundwater discharge (SGD) in Masan Bay, an embayment surrounded by heavily industrialized cities, Korea. Sci. Total Environ. 407, 3181-3188. doi: 10.1016/j.scitotenv.2008. 04.013

Leitão, F., Encarnação, J., Range, P., Schmelz, R. M., Teodósio, M. A., and Chícharo, L. (2015). Submarine groundwater discharges create unique benthic communities in a coastal sandy marine environment. Estuar. Coast. Shelf Sci. 163, 93-98. doi: 10.1016/j.ecss.2015.06.007

Li, L., and Barry, D. A. (2000). Wave-induced beach groundwater flow. Adv. Water Res. 23, 325-337. doi: 10.1016/S0309-1708(99)00032-9

Li, L., Barry, D. A., Stagnitti, F., Parlange, J. Y., and Jeng, D. S. (2000). Beach water table fluctuations due to spring-neap tides: moving boundary effects. $A d v$. Water Res. 23, 817-824. doi: 10.1016/S0309-1708(00)00017-8

Liu, Q., Dai, M., Chen, W., Huh, C. A., Wang, G., Charette, M. A., et al. (2012). How significant is submarine groundwater discharge and its associated dissolved inorganic carbon in a river-dominated shelf system? Biogeosciences 9 , 1777-1795. doi: 10.5194/bg-9-1777-2012

Lorah, M. M., Cozzarelli, I. M., and Böhlke, J. K. (2009). Biogeochemistry at a wetland sediment-alluvial aquifer interface in a landfill leachate plume. $J$. Contamin. Hydrol. 105, 99-117. doi: 10.1016/j.jconhyd.2008.11.008

Lubis, R. F., and Bakti, H. (2013). Mata Air Tawar Di Tengah Laut. Geomagz $3,38-42$. 
Luijendijk, E., Gleeson, T., and Moosdorf, N. (2019). The flow of fresh groundwater and solutes to the World's oceans and coastal ecosystems. EarthArXiv. doi: $10.31223 /$ osf.io/sw8r4

Luo, X., Jiao, J. J., Liu, Y., Zhang, X., Liang, W., and Tang, D. (2018). Evaluation of water residence time, submarine groundwater discharge, and maximum new production supported by groundwater borne nutrients in a coastal upwelling shelf system. J. Geophys. Res. 123, 631-655. doi: 10.1002/2017JC013398

Luo, X., Jiao, J. J., Moore, W. S., and Lee, C. M. (2014). Submarine groundwater discharge estimation in an urbanized embayment in Hong Kong via short-lived radium isotopes and its implication of nutrient loadings and primary production. Mar. Pollut. Bull. 82, 144-154. doi: 10.1016/j.marpolbul.2014.03.005

Maher, D. T., Call, M., Macklin, P., Webb, J. R., and Santos, I. R. (2019). Hydrological versus biological drivers of nutrient and carbon dioxide dynamics in a Coastal Lagoon. Estuar. Coasts. 42, 1015-1031. doi: 10.1007/s12237-019-00532-2

Manheim, F. T., Krantz, D. E., and Bratton, J. F. (2004). Studying ground water under Delmarva coastal bays using electrical resistivity. Groundwater 42, 1052-1068. doi: 10.1111/j.1745-6584.2004.tb02643.x

Martinsson-Wallin, H., and Crockford, S. J. (2001). Early Settlement of Rapa Nui (Easter Island). Asian Perspect. 40, 244-278. doi: 10.1353/asi.2001.0016

Mathieu, G. G., Biscaye, P. E., Lupton, R. A., and Hammond, D. E. (1988). System for measurement of 222Rn at low levels in natural waters. Health Phys. 55, 989-992. doi: 10.1097/00004032-198812000-00015

McClelland, J. W., and Valiela, I. (1998). Linking nitrogen in estuarine producers to land-derived sources. Limnol. Oceanogr. 43, 577-585. doi: 10.4319/lo.1998.43.4.0577

McMahon, A., and Santos, I. R. (2017). Nitrogen enrichment and speciation in a coral reef lagoon driven by groundwater inputs of bird guano. J. Geophys. Res. 122, 7218-7236. doi: 10.1002/2017JC012929

Michael, H. A., Lubetsky, J. S., and Harvey, C. F. (2003). Characterizing submarine groundwater discharge: a seepage meter study in Waquoit Bay, Massachusetts. Geophys. Res. Lett. 30, 1297-1301. doi: 10.1029/2002GL016000

Michael, H. A., Mulligan, A. E., and Harvey, C. F. (2005). Seasonal oscillations in water exchange between aquifers and the coastal ocean. Nature 436, 1145-1148. doi: 10.1038 /nature03935

Michael, H. A., Post, V. E. A., Wilson, A. M., and Werner, A. D. (2017). Science, society, and the coastal groundwater squeeze. Water Res. Res. 53, 2610-2617. doi: 10.1002/2017WR020851

Michael, H. A., Scott, K. C., Koneshloo, M., Yu, X., Khan, M. R., and Li, K. (2016). Geologic influence on groundwater salinity drives large seawater circulation through the continental shelf. Geophys. Res. Lett. 43, 782-791. doi: 10.1002/2016GL070863

Miller, D. C., and Ullman, W. J. (2004). Ecological consequences of ground water discharge to Delaware Bay, United States. Groundwater 42, 959-970. doi: 10.1111/j.1745-6584.2004.tb02635.x

Moffett, K. B., Gorelick, S. M., McLaren, R. G., and Sudicky, E. A. (2012). Salt marsh ecohydrological zonation due to heterogeneous vegetationgroundwater-surface water interactions. Water Resour. Res. 48:W02516. doi: 10.1029/2011WR010874

Moore, W. S. (1996). Large groundwater inputs to coastal waters revealed by ${ }^{226} \mathrm{Ra}$ enrichments. Nature 380, 612-614. doi: 10.1038/380612a0

Moore, W. S. (1999). The subterranean estuary: a reaction zone of ground water and sea water. Mar. Chem. 65, 111-126. doi: 10.1016/S0304-4203(99)00014-6

Moore, W. S. (2010). The effect of submarine groundwater discharge on the ocean. Annu. Rev. Mar. Sci. 2, 59-88. doi: 10.1146/annurev-marine-120308-081019

Moore, W. S., and Arnold, R. (1996). Measurement of ${ }^{223} \mathrm{Ra}$ and ${ }^{224} \mathrm{Ra}$ in coastal waters using a delayed coincidence counter. J. Geophys. Res. 101, 1321-1329. doi: 10.1029/95JC03139

Moore, W. S., Sarmiento, J. L., and Key, R. M. (2008). Submarine groundwater discharge revealed by ${ }^{228} \mathrm{Ra}$ distribution in the upper Atlantic. Nat. Geosci. 1, 309-311. doi: 10.1038/ngeo183

Moosdorf, N., and Oehler, T. (2017). Societal use of fresh submarine groundwater discharge: An overlooked water resource. Earth Sci. Rev. 171, 338-348. doi: 10.1016/j.earscirev.2017.06.006

Moosdorf, N., Stieglitz, T., Waska, H., Durr, H. H., and Hartmann, J. (2015). Submarine groundwater discharge from tropical islands: a review. Grundwasser 20, 53-67. doi: 10.1007/s00767-014-0275-3
Mulligan, A. E., and Charette, M. A. (2006). Intercomparison of submarine groundwater discharge estimates from a sandy unconfined aquifer. J. Hydrol. 327, 411-425. doi: 10.1016/j.jhydrol.2005.11.056

Mulligan, A. E., Evans, R. L., and Lizarralde, D. (2007). The role of paleochannels in groundwater/seawater exchange. J. Hydrol. 335, 313-329. doi: 10.1016/j.jhydrol.2006.11.025

Nelson, C. N., Donahue, M. J., Dulaiova, H., Goldberg, S. J., La Valle, F. F., Lubarsky, K., et al. (2015). Fluorescent dissolved organic matter as a multivariate biogeochemical tracer of submarine groundwater discharge in coral reef ecosystems. Mar. Chem. 177, 232-243. doi: 10.1016/j.marchem. 2015.06.026

Nielsen, P. (1990). Tidal dynamics of the water table in beaches. Water Resour. Res. 26, 2127-2134. doi: 10.1029/WR026i009p02127

Nielsen, P. (1999). Groundwater dynamics and salinity in coastal barriers. J. Coastal Res. 15, 732-740.

Oehler, T., Bakti, H., Lubis, R. F., Purwoarminta, A., Delinom, R., and Moosdorf, N. (2019). Nutrient dynamics in submarine groundwater discharge through a coral reef (western Lombok, Indonesia). Limnol. Oceanogr. doi: 10.1002/lno.11240. [Epub ahead of print].

Oehler, T., Eiche, E., Putra, D., Adyasari, D., Hennig, H., Mallast, U., et al (2018). Seasonal variability of land-ocean groundwater nutrient fluxes from a tropical karstic region (southern Java, Indonesia). J. Hydrol. 565, 662-671. doi: 10.1016/j.jhydrol.2018.08.077

Oh, Y. H., and Kim, G. (2016). Large scale seasonal changes in the recharge of seawater in a subterranean estuary revealed by a radon tracer. Hydrol. Process. 30, 2525-2532. doi: 10.1002/hyp.10807

Oki, T., and Kanae, S. (2006). Global hydrological cycles and world water resources. Science 313, 1068-1072. doi: 10.1126/science.1128845

Ouisse, V., Riera, P., Migné, A., Leroux, C., and Davoult, D. (2011). Freshwater seepages and ephemeral macroalgae proliferation in an intertidal bay: I Effect on benthic community structure and food web. Estuar. Coast. Shelf Sci. 91, 272-281. doi: 10.1016/j.ecss.2010.10.034

Patritis, D. L., Tsabaris, C., Schmidt, M., Karageorgis, A. P., Prospathopoulos, A. M., Alexakis, S., et al. (2018). Mobile underwater in stitu gammas ray spectroscopy to localize groundwater emanation from pockmarks in the Eckernforde bay, Germany. Appl. Radiat. Isotopes 140, 305-313. doi: 10.1016/j.apradiso.2018.07.037

Paulsen, R. J., Smith, C. F., O’Rourke, D., and Wong, T. (2001). Development and evaluation of an ultrasonic ground water seepage meter. Groundwater 39, 904-911. doi: 10.1111/j.1745-6584.2001.tb02478.x

Petermann, E., and Schubert, M. (2015). Quantification of the response delay of mobile radon-in-air detectors applied for detecting short-term fluctuations of radon-in-water concentrations. Eur. Phys. J. Spec. Top. 224, 697-707. doi: 10.1140/epjst/e2015-02400-5

Piló, D., Barbosa, A. B., Teodósio, M. A., Encarnação, J., Leitão, F., Range, P., et al. (2018). Are submarine groundwater discharges affecting the structure and physiological status of rocky intertidal communities? Mar. Environ. Res. 136, 158-173. doi: 10.1016/j.marenvres.2018.02.013

Pongkijvorasin, S., Burnett, K., and Wada, C. A. (2018). Joint management of an interconnected coastal aquifer and invasive tree. Ecol. Econ. 146, 125-135. doi: 10.1016/j.ecolecon.2017.10.011

Pongkijvorasin, S., Roumasset, J., Duarte, T., and Burnett, K. (2010). Renewable resource management with stock externalities: coastal aquifers and submarine groundwater discharge. Res. Energy Econ. 32, 277-291. doi: 10.1016/j.reseneeco.2009.09.001

Post, V. E., Groen, J., Kooi, H., Person, M., Ge, S., and Edmunds, W. M. (2013). Offshore fresh groundwater reserves as a global phenomenon. Nature 504, 71-78. doi: $10.1038 /$ nature 12858

Potts, D. T. (1985). Reflections on the history and archaeology of Bahrain. J. Am. Orient. Soc. 105, 675-710. doi: 10.2307/602727

Povinec, P. P., Comanducci, J.-F., Levy-Palomo, I., and Oregioni, B. (2006). Monitoring of submarine groundwater discharge along the Donnalucata coast in the south-eastern Sicily using underwater gamma-ray spectrometry. Continent. Shelf Res. 26, 874-884. doi: 10.1016/j.csr.2005.12.009

Rahman, S., Tamborski, J. J., Charette, M. A., and Cochran, J. K. (2019). Dissolved silica in the subterranean estuary and the impact of submarine groundwater discharge on the global marine silica budget. Mar. Chem. 208, 29-42. doi: 10.1016/j.marchem.2018.11.006 
Rausch, R., Dirks, H., Kallioras, A., and Schuth, C. (2014). The Riddle of the springs of dilmun-does the Gilgamesh Epic tell the truth? Groundwater 52, 640-644. doi: $10.1111 /$ gwat. 12214

Robinson, C., Brovelli, A., Barry, D. A., and Li, L. (2009). Tidal influence on BTEX biodegradation in sandy coastal aquifers. Adv. Water Res. 32, 16-28. doi: 10.1016/j.advwatres.2008.09.008

Robinson, C., Gibbes, B., and Li, L. (2006). Driving mechanisms for groundwater flow and salt transport in a subterranean estuary. Geophys. Res. Lett. 33:L03402. doi: 10.1029/2005GL025247

Robinson, C., Li, L., and Barry, D. A. (2007). Effect of tidal forcing on a subterranean estuary. Adv. Water Res. 30, 851-865. doi: 10.1016/j.advwatres.2006.07.006

Robinson, C., Xin, P., Li, L., and Barry, D. A. (2014). Groundwater flow and salt transport in a subterranean estuary driven by intensified wave conditions. Water Resour. Res. 50, 1-17. doi: 10.1002/2013WR013813

Robinson, C. E., Xin, P., Santos, I. R., Charette, M. A., Li, L., and Barry, D. A. (2018). Groundwater dynamics in subterranean estuaries of coastal unconfined aquifers: Controls on submarine groundwater discharge and chemical inputs to the ocean. Adv. Water Res. 115, 315-331. doi: 10.1016/j.advwatres.2017.10.041

Rocha, C., Veiga-Pires, C., Scholten, J., Knoeller, K., Gröcke, D. R., Carvalho, L., et al. (2016). Assessing land-ocean connectivity via submarine groundwater discharge (SGD) in the Ria Formosa Lagoon (Portugal): combining radon measurements and stable isotope hydrology. Hydrol. Earth Syst. Sci. 20, 3077-3098. doi: 10.5194/hess-20-3077-2016

Rodellas, V., Garcia-Orellana, J., Masqué, P., Feldman, M., and Weinstein, Y. (2015a). Submarine groundwater discharge as a major source of nutrients to the Mediterranean Sea. Proc. Natl. Acad. Sci. U.S.A. 112, 3926-3930. doi: 10.1073/pnas.1419049112

Rodellas, V., Garcia-Orellana, J., Trezzi, G., Masque, P., Berdalet, E., Bokuniewicz, H. J., et al. (2015b). "Seasonal cycles in radium fluxes to a Mediterranean Bay: submarine groundwater discharge vs porewater advection," in 2015 Aquatic Sciences Meeting. Program Book (Granada), 64.

Röper, T., Greskowiak, J., and Massmann, G. (2014). Detecting small groundwater discharge springs using handheld thermal infrared imagery. Groundwater 52, 936-942. doi: 10.1111/gwat.12145

Röper, T., Greskowiak, J., and Massmann, G. (2015). Instabilities of submarine groundwater discharge under tidal forcing. Limnol. Oceanogr. 60, 22-28. doi: 10.1002/lno.10005

Rousakis, G., Karageorgis, A. P., and Georgiou, P. (2014). Geological structure and seabed morphology of the Stoupa submarine groundwater discharge system, Messinia, Greece. Environ. Earth Sci. 71, 5059-5069. doi: 10.1007/s12665-013-2910-1

Sadat-Noori, M., Maher, D. T., and Santos, I. R. (2016). Groundwater discharge as a source of dissolved carbon and greenhouse gases in a subtropical estuary. Estuar. Coasts 39, 639-656. doi: 10.1007/s12237-015-0042-4

Sadat-Noori, M., Santos, I. R., Sanders, C. J., Sanders, L. M., and Maher, D. T. (2015). Groundwater discharge into an estuary using spatially distributed radon time series and radium isotopes. J. Hydrol. 528, 703-719. doi: 10.1016/j.jhydrol.2015.06.056

Sadat-Noori, M., Santos, I. R., Tait, D. R., Reading, M. J., and Sanders, C. J. (2017). High porewater exchange in a mangrove-dominated estuary revealed from short-lived radium isotopes. J. Hydrol. 553, 188-198. doi: 10.1016/j.jhydrol.2017.07.058

Santos, I. R., Burnett, W. C., Chanton, J., Dimova, N., and Peterson, R. (2009). Land or ocean?: assessing the driving forces of submarine groundwater discharge at a coastal site in the Gulf of Mexico. J. Geophys. Res. 114:C04012. doi: 10.1029/2008JC005038

Santos, I. R., Burnett, W. C., Chanton, J., Mwashote, B., Suryaputra, I. G. N. A., and Dittmar, T. (2008). Nutrient biogeochemistry in a Gulf of Mexico subterranean estuary and groundwater-derived fluxes to the coastal ocean. Limnol. Oceanogr. 53, 705-718. doi: 10.4319/lo.2008.53.2.0705

Santos, I. R., Eyre, B. D., and Huettel, M. (2012b). The driving forces of porewater and groundwater flow in permeable coastal sediments: a review. Estuar. Coast. Shelf Sci. 98, 1-15. doi: 10.1016/j.ecss.2011.10.024

Santos, I. R., Maher, D. T., and Eyre, B. D. (2012a). Coupling automated radon and carbon dioxide measurements in coastal waters. Environ. Sci. Technol. 46, 7685-7691. doi: 10.1021/es301961b
Santos, I. R., Maher, D. T., Larkin, R., Webb, J. R., and Sanders, C. J. (2019). Carbon outwelling and outgassing vs. burial in an estuarine tidal creek surrounded by mangrove and saltmarsh wetlands. Limnol. Oceanogr. 64, 996-1013. doi: 10.1002/lno.11090

Santos-Echeandia, J., Prego, R., Cobelo-García, A., and Millward, G. E. (2009). Porewater geochemistry in a Galician Ria (NW Iberian Peninsula): implications for benthic fluxes of dissolved trace elements $(\mathrm{Co}, \mathrm{Cu}, \mathrm{Ni}, \mathrm{Pb}, \mathrm{V}, \mathrm{Zn}) . \mathrm{Mar}$. Chem. 117, 77-87. doi: 10.1016/j.marchem.2009.05.001

Sawyer, A. H., Shi, F., Kirby, J. T., and Michael, H. A. (2013). Dynamic response of surface water-groundwater exchange to currents, tides, and waves in a shallow estuary. J. Geophys. Res. C 118, 1749-1758. doi: 10.1002/jgrc.20154

Schlüter, M., Sauter, E. J., Andersen, C. E., Dahlgaard, H., and Dando, P. R. (2004). Spatial distribution and budget for submarine groundwater discharge in Eckernförde Bay (Western Baltic Sea). Limnol. Oceanogr. 49, 157-167. doi: 10.4319/lo.2004.49.1.0157

Schubert, M., Petermann, E., Stollberg, R., Gebel, M., Scholten, J., Knöller, K., et al. (2019). Improved approach for the investigation of submarine groundwater discharge by means of radon mapping and radon mass balancing. Water 11:749. doi: 10.3390/w11040749

Seidel, M., Beck, M., Greskowiak, J., Riedel, T., Waska, H., Suryaputra, I. G. N. A., et al. (2015). Benthic-pelagic coupling of nutrients and dissolved organic matter composition in an intertidal sandy beach. Mar. Chem. 176, 150-163. doi: 10.1016/j.marchem.2015.08.011

Seidel, M., Beck, M., Riedel, T., Waska, H., Suryaputra, I. G. N. A., Schnetger, B., et al. (2014). Biogeochemistry of dissolved organic matter in an anoxic intertidal creek bank. Geochim. Cosmochim. Acta 140, 418-434. doi: 10.1016/j.gca.2014.05.038

Shoji, J., Mitamura, H., Ichikawa, K., Kinoshita, H., and Arai, N. (2017). Increase in predation risk and trophic level induced by nocturnal visits of piscivorous fishes in a temperate seagrass bed. Sci. Rep. 7:3895. doi: 10.1038/s41598-017-04217-3

Shoji, J., and Tominaga, O. (2018). "Relationships between submarine groundwater discharge and coastal fisheries as a water-food nexus," in The Water-Energy-Food Nexus, eds A. Endo and T. Oh (Singapore: Springer), 117-131.

Sholkovitz, E. R., Herbold, C., and Charette, M. A. (2003). An automated dye-dilution based seepage meter for the time-series measurement of submarine groundwater discharge. Limnol. Oceanogr. Methods 1, 16-28. doi: 10.4319/lom.2003.1.16

Shuler, C. K., Amato, D. W., Veronica Gibson, V., Baker, L., Olguin, A. N., and Dulai, H. (2019). Assessment of terrigenous nutrient loading to coastal ecosystems along a human land-use gradient, Tutuila, American Samoa. Hydrology 6:18. doi: 10.3390/hydrology6010018

Smith, C. G., Cable, J. E., and Martin, J. B. (2008). Episodic high intensity mixing events in a subterranean estuary: effects of tropical cyclones. Limnol. Oceanogr. 53, 666-674. doi: 10.4319/lo.2008.53.2.0666

Spiteri, C., Slomp, C. P., Tuncay, K., and Meile, C. (2008). Modeling biogeochemical processes in subterranean estuaries: effect of flow dynamics and redox conditions on submarine groundwater discharge of nutrients. Water Res. Res. 44:W02430. doi: 10.1029/2008WR006997

Stewart, B., Bryan, K. R., Pilditch, C. A., and Santos, I. R. (2018). Submarine groundwater discharge estimates using radium isotopes and related nutrient inputs into Tauranga Harbour (New Zealand). Estuar. Coasts 41, 384-403. doi: 10.1007/s12237-017-0290-6

Stewart, B. T., Santos, I. R., Tait, D., Macklin, P. A., and Maher, D. T. (2015). Submarine groundwater discharge and associated fluxes of alkalinity and dissolved carbon into Moreton Bay (Australia) estimated via radium isotopes. Mar. Chem. 174, 1-12. doi: 10.1016/j.marchem.2015.03.019

Stieglitz, T. (2005). Submarine groundwater discharge into the near-shore zone of the Great Barrier Reef, Australia. Mar. Pollut. Bull. 51, 51-59. doi: 10.1016/j.marpolbul.2004.10.055

Stieglitz, T., Clark, J. F., and Hancock, G. J. (2013). The mangrove pump: The tidal flushing of animal burrows in a tropical mangrove forest determined from radionuclide budgets. Geochim. Cosmochim. Acta 102, 12-22. doi: 10.1016/j.gca.2012.10.033

Stieglitz, T., Rapaglia, J., and Bokuniewicz, H. (2008a). Estimation of submarine groundwater discharge from bulk ground electrical conductivity measurements. J. Geophys. Res. 113:C08007. doi: 10.1029/2007JC004499 
Stieglitz, T., and Ridd, P. (2000). "Submarine groundwater discharge from paleochannels?: 'Wonky Holes' on the inner shelf of the great barrier reef, Australia," in Hydro 2000: Interactive Hydrology; Proceedings (Perth, WA), 189-194.

Stieglitz, T., Taniguchi, M., and Neylon, S. (2008b). Spatial variability of submarine groundwater discharge, Ubatuba, Brazil. Estuar. Coast. Shelf Sci. 76, 493-500. doi: 10.1016/j.ecss.2007.07.038

Stieglitz, T. C., and Dujon, A. M. (2017). A groundwater-fed coastal inlet as habitat for the Caribbean queen conch Lobatus gigas an acoustic telemetry and space use analysis. Mar. Ecol. Prog. Ser. 571, 139-152. doi: 10.3354/meps12123

Stieglitz, T. C., Rapaglia, J., and Krupa, S. C. (2007). An effect of pier pilings on nearshore submarine groundwater discharge from a (partially) confined aquifer. Estuar. Coasts 30, 543-550. doi: 10.1007/BF03036520

Street, J. H., Knee, K. L., Grossman, E. E., and Paytan, A. (2008), Submarine groundwater discharge and nutrient addition to the coastal zone and coral reefs of leeward Hawaii. Mar. Chem. 109, 355-376. doi: 10.1016/j.marchem.2007.08.009

Su, N., Burnett, W. C., MacIntyre, H. L., Liefer, J. D., Peterson, R. N., and Viso, R. (2014). Natural radon and radium isotopes for assessing groundwater discharge into Little Lagoon, Alabama: implications for harmful algal blooms. Estuar. Coasts 37, 893-910. doi: 10.1007/s12237-013-9734-9

Sugimoto, R., Kasai, A., Miyajima, T., and Fujita, K. (2010). Modeling phytoplankton production in Ise Bay, Japan: Use of nitrogen isotopes to identify dissolved inorganic nitrogen sources. Estuar. Coast. Shelf Sci. 86, 450-466. doi: 10.1016/j.ecss.2009.10.011

Sugimoto, R., Kitagawa, K., Nishi, S., Honda, H., Yamada, M., and Kobayashi, S. (2017). Phytoplankton primary productivity around submarine groundwater discharge in nearshore coasts. Mar. Ecol. Prog. Ser. 563, 25-33. doi: 10.3354/meps11980

Sugimoto, R., Sato, T., Yoshida, T., and Tominaga, O. (2014). Using stable nitrogen isotopes to evaluate the relative importance of external and internal nitrogen loadings on phytoplankton production in a shallow eutrophic lake (Lake Mikata, Japan). Limnol. Oceanogr. 59, 37-47. doi: 10.4319/lo.2014.59.1.0037

Suryaputra, I. G. N. A., Santos, I. R., Huettel, M., Burnett, W. C., and Dittmar, T. (2015). Non-conservative behavior of fluorescent dissolved organic matter (FDOM) within a subterranean estuary. Continent. Shelf Res. 110, 183-190. doi: 10.1016/j.csr.2015.10.011

Swarzenski, P. W., Burnett, W. C., Greenwood, W. J., Herut, B., Peterson, R., Dimova, N., et al. (2006). Combined time-series resistivity and geochemical tracer techniques to examine submarine groundwater discharge at Dor Beach, Israel. Geophys. Res. Lett. 33:L24405. doi: 10.1029/2006GL028282

Swarzenski, P. W., Dulaiova, H., Kroeger, K. D., Smith, C. G., Dimova, N., Storlazzi, C. D., et al. (2016). Observations of offshore groundwater flow: Kahekili Beach Park submarine springs, Maui, Hawaii. J. Hydrol. 11, 147-165. doi: 10.1016/j.ejrh.2015.12.056

Tachikawa, K., Athias, V., and Jeandel, C. (2003). Neodymium budget in the modern ocean and paleo-oceanographic implications. J. Geophys. Res. 108:3254. doi: 10.1029/1999JC000285

Tait, D. R., Maher, D. T., Macklin, P. A., and Santos, I. R. (2016). Mangrove pore water exchange across a latitudinal gradient. Geophys. Res. Lett.43, 3334-3341. doi: 10.1002/2016GL068289

Tait, D. R., Maher, D. T., Sanders, C. J., and Santos, I. R. (2017). Radium-derived porewater exchange and dissolved $\mathrm{N}$ and $\mathrm{P}$ fluxes in mangroves. Geochim. Cosmochim. Acta 200, 295-309. doi: 10.1016/j.gca.2016. 12.024

Tamborski, J., Bejannin, S., Garcia-Orellana, J., Souhaut, M., Charbonnier, C., Anschutz, P., et al. (2018). A comparison between water circulation and terrestrially-driven dissolved silica fluxes to the Mediterranean Sea traced using radium isotopes. Geochim. Cosmochim. Acta 238, 496-515. doi: 10.1016/j.gca.2018.07.022

Tamborski, J. J., Cochran, J. K., and Bokuniewicz, H. J. (2017a). Application of $224 \mathrm{Ra}$ and $222 \mathrm{Rn}$ for evaluating seawater residence times in a tidal subterranean estuary. Mar. Chem. 189, 32-45. doi: 10.1016/j.marchem.2016.12.006

Tamborski, J. J., Cochran, J. K., and Bokuniewicz, H. J. (2017b). Submarine groundwater discharge driven nitrogen fluxes to Long Island Sound, NY: Terrestrial vs. marine sources. Geochim. Cosmochim. Acta 218, 40-57. doi: 10.1016/j.gca.2017.09.003
Tamborski, J. J., Rogers, A. D., Bokuniewicz, H. J., Cochran, J. K., and Young, C. R. (2015). Identification and quantification of diffuse fresh submarine groundwater discharge via airborne thermal infrared remote sensing. Remote Sens. Environ. 171, 202-217. doi: 10.1016/j.rse.2015.10.010

Tang, J., and Johannesson, K. H. (2005). "Rare earth element concentrations, speciation, and fractionation along groundwater flow paths: the carrizo sand (Texas) and upper floridan aquifers," in Rare Earth Elements in Groundwater Flow Systems, Vol. 51. Water Science and Technology Library, ed K. H. Johannesson (Dordrecht: Springer), 223-251.

Tang, J., and Johannesson, K. H. (2006). Controls on the geochemistry of rare earth elements along a groundwater flow path in the Carrizo Sand aquifer, Texas, USA. Chem. Geol. 225, 156-171. doi: 10.1016/j.chemgeo.2005.09.007

Taniguchi, M., Burnett, W. C., Cable, J. E., and Turner, J. V. (2002). Investigation of submarine groundwater discharge. Hydrol. Process. 16, 2115-2129. doi: 10.1002/hyp.1145

Taniguchi, M., and Fukuo, Y. (1993). Continuous measurements of groundwater seepage using an automatic seepage meter. Groundwater 31, 675-679. doi: 10.1111/j.1745-6584.1993.tb00601.x

Taniguchi, M., Ishitobi, T., and Shimada, J. (2006). Dynamics of submarine groundwater discharge and freshwater-seawater interface. J. Geophys. Res. 111:C01008. doi: 10.1029/2005JC002924

Taniguchi, M., and Iwakawa, H. (2004). Submarine groundwater discharge in Osaka Bay, Japan. Limnology 5, 25-32. doi: 10.1007/s10201-003-0112-3

Taniguchi, M., Ono, M., and Takahashi, M. (2015). Multi-scale evaluations of submarine groundwater discharge. Proc. IAHS 365, 66-71. doi: 10.5194/piahs-365-66-2015

Taniguchi, M., Stieglitz, T., and Ishitobi, T. (2008). Temporal variability of water quality of submarine groundwater discharge in Ubatuba, Brazil. Estuar. Coast. Shelf Sci. 76, 484-492. doi: 10.1016/j.ecss.2007.07.019

Trezzi, G., Garcia-Orellana, J., Rodellas, V., Santos-Echeandia, J., Tovar-Sánchez, A., Garcia-Solsona, E., et al. (2016). Submarine groundwater discharge: A significant source of dissolved trace metals to the North Western Mediterranean Sea. Mar. Chem. 186, 90-100. doi: 10.1016/j.marchem.2016.08.004

Troccoli-Ghinaglia, L., Herrera-Silveira, J. A., Comín, F. A., and Díaz-Ramos, J. R. (2010). Phytoplankton community variations in tropical coastal area affected where submarine groundwater occurs. Continent. Shelf Res. 30, 2082-2091. doi: 10.1016/j.csr.2010.10.009

Tsabaris, C., Patritis, D. L., Karageorgis, A. P., Eleftheriou, G., Papadopoulos, V. P., Georgopoulos, D., et al. (2012). In-situ radionuclide characterization of a submarine groundwater discharge site at Kalogria Bay, Stoupa, Greece. J. Environ. Radioactiv. 108, 50-59. doi: 10.1016/j.jenvrad.2011.08.005

Umezawa, Y., Miyajima, T., Yamamuro, M., Kayanne, H., and Koike, I. (2002). Fine-scale mapping of land-derived nitrogen in coral reefs by $15 \mathrm{~N}$ in macroalgae. Limnol. Oceanogr. 47, 1405-1416. doi: 10.4319/lo.2002.47.5.1405

Utsunomiya, T., Hata, M., Sugimoto, R., Honda, H., Kobayashi, S., Miyata, Y., et al. (2017). Higher species richness and abundance of fish and benthic invertebrates around submarine groundwater discharge in Obama Bay, Japan. J. Hydrol. 11, 139-146. doi: 10.1016/j.ejrh.2015.11.012

Valiela, I., Costa, J., Foreman, K., Teal, J. M., Howes, B., and Aubrey, D. (1990). Transport of groundwater-borne nutrients from watersheds and their effects on coastal waters. Biogeochemistry 10, 177-197. doi: 10.1007/BF00003143

Valiela, I., and D'Elia, C. (1990). Groundwater inputs to coastal waters. Biogeochemistry 10, 175-335. doi: 10.1007/BF00003142

Varma, S., Turner, J., and Underschultz, J. (2010). Estimation of submarine groundwater discharge into Geographe Bay, Bunbury, Western Australia. J. Geochem. Expl. 106, 197-210. doi: 10.1016/j.gexplo.2010.02.003

Viso, R., McCoy, C., Gayes, P., and Quafisi, D. (2010). Geological controls on submarine groundwater discharge in Long Bay, South Carolina (USA). Continent. Shelf Res. 30, 335-341. doi: 10.1016/j.csr.2009.11.014

Wang, G., Wang, Z., Zhai, W., Moore, W. S., Li, Q., Yan, X., et al. (2015). Net subterranean estuarine export fluxes of dissolved inorganic C, N, P, Si, and total alkalinity into the Jiulong River estuary, China. Geochim. Cosmochim. Acta 149, 103-114. doi: 10.1016/j.gca.2014.11.001

Wang, X., Li, H., Zheng, C., Yang, J., Zhang, Y., and Zhang, M. (2018). Submarine groundwater discharge as an important nutrient source influencing nutrient structure in coastal water of Daya Bay, China. Geochim. Cosmochim. Acta 225, 52-65. doi: 10.1016/j.gca.2018.01.029 
Waska, H., and Kim, G. (2010). Differences in microphytobenthos and macrofaunal abundances associated with groundwater discharge in the intertidal zone. Mar. Ecol. Prog. Ser. 407, 159-172. doi: 10.3354/meps 08568

Waska, H., and Kim, G. (2011). Submarine groundwater discharge (SGD) as a main nutrient source for benthic and water-column primary production in a large intertidal environment of the Yellow Sea. J. Sea Res. 65, 103-113. doi: 10.1016/j.seares.2010.08.001

Webb, J. R., Santos, I. R., Maher, D. T., Tait, D. R., Cyronak, T., Sadat-Noori, M., et al. (2019). Groundwater as a source of dissolved organic matter to coastal waters: Insights from radon and CDOM observations in 12 shallow coastal systems. Limnol. Oceanogr. 64, 182-196. doi: 10.1002/lno.11028

Welti, N., Gale, D., Hayes, M., Kumar, A., Gasparon, M., Gibbes, B., et al. (2015). Intertidal diatom communities reflect patchiness in groundwater discharge. Estuar. Coast. Shelf Sci. 163, 116-124. doi: 10.1016/j.ecss.2015.06.006

Williams, M. O. (1946). Bahrein: port of pearls and petroleum. Natl. Geogr. Mag. $89,198-210$

Willis, S. S., and Johannesson, K. H. (2011). Controls on the geochemistry of rare earth elements in sediments and groundwaters of the Aquia aquifer, Maryland, USA. Chem. Geol. 285, 32-49. doi: 10.1016/j.chemgeo.2011.02.020

Wilson, A., and Morris, J. (2012). The influence of tidal forcing on groundwater flow and nutrient exchange in a salt marsh-dominated estuary. Biogeochemistry 108, 27-38. doi: 10.1007/s10533-010-9570-y

Wilson, A. M., Evans, T. B., Moore, W. S., Schutte, C. A., and Joye, S. B. (2015). What time scales are important for monitoring tidally influenced submarine groundwater discharge? Insights from a salt marsh. Water Resour. Res. 51, 4198-4207. doi: 10.1002/2014WR015984

Wilson, J., and Rocha, C. (2012). Regional scale assessment of submarine groundwater discharge in Ireland combining medium resolution satellite imagery and geochemical tracing techniques. Remote Sens. Environ. 119, 21-34. doi: 10.1016/j.rse.2011.11.018

Xin, P., Kong, J., Li, L., and Barry, D. A. (2012). Effects of soil stratigraphy on pore-water flow in a creek-marsh system. J. Hydrol. 475, 175-187. doi: 10.1016/j.jhydrol.2012.09.047

Xin, P., Robinson, C., Li, L., Barry, D. A., and Bakhtyar, R. (2010). Effects of wave forcing on a subterranean estuary. Water Resour. Res. 46:W12505. doi: 10.1029/2010WR009632

Xin, P., Wang, S. S. J., Lu, C., Robinson, C., and Li, L. (2015). Nonlinear interactions of waves and tides in a subterranean estuary. Geophys. Res. Lett. 42, 2277-2284. doi: 10.1002/2015GL063643

Xin, P., Wang, S. S. J., Robinson, C., Li, L., Wang, Y.-G., and Barry, D. A. (2014). Memory of past random wave conditions in submarine groundwater discharge. Geophys. Res. Lett. 41, 2401-2410. doi: 10.1002/2014GL059617

Xin, P., Yuan, L. R., Li, L., and Barry, D. A. (2011). Tidally driven multiscale pore water flow in a creek-marsh system. Water Resour. Res. 47:W07534. doi: 10.1029/2010WR010110

Xu, B., Burnett, W. C., Dimova, N., Diao, S., Mi, T., Jiang, X., et al. (2013). Hydrodynamics in the Yellow River Estuary via radium isotopes: ecological perspectives. Continent. Shelf Res. 66, 19-28. doi: 10.1016/j.csr.2013. 06.018

Xu, B., Xia, D., Burnett, W. C., Dimova, N. T., Wang, H., Zhang, L., et al. (2014). Natural ${ }^{222} \mathrm{Rn}$ and ${ }^{220} \mathrm{Rn}$ indicate the impact of the Water-Sediment Regulation Scheme (WSRS) on submarine groundwater discharge in the Yellow River Estuary, China. Appl. Geochem. 51, 79-85. doi: 10.1016/j.apgeochem.2014. 09.018

$\mathrm{Xu}, \mathrm{Y}$., and Marcantonio, F. (2004). Speciation of strontium in particulates and sediments from the Mississippi River mixing zone. Geochim. Cosmochim. Acta 68, 2649-2657. doi: 10.1016/j.gca.2003.12.016

Yamane, K., Murase, I., Shirafuji, N., Hayashi, A., Nagakura, Y., and Watanabe, Y. (2019). Nursery habitat use for larval and juvenile Pacific herring Clupea pallasii in Miyako Bay on the Pacific coast of northern Japan. Fish. Sci. 85, 407-416. doi: 10.1007/s12562-019-01301-7

York, J. K., Tomasky, G., Valiela, I., and Repeta, D. J. (2007). Stable isotopic detection of ammonium and nitrate assimilation by phytoplankton in the Waquoit Bay estuarine system. Limnol. Oceanogr. 52, 144-155. doi: 10.4319/lo.2007.52.1.0144

Yu, X., Xin, P., Lu, C., Robinson, C., Li, L., and Barry, D. A. (2017). Effects of episodic rainfall on a subterranean estuary. Water Resour. Res. 53, 5774-5787. doi: 10.1002/2017WR020809

Zektser, I. S., and Everett, L. G. (2000). Groundwater and the Environment: Applications for the Global Community. Boca Raton, FL: Lewis Publishers. doi: $10.1201 / 9781420032895$

Zhang, Y., Li, L., Erler, D. V., Santos, I., and Lockington, D. (2016). Effects of alongshore morphology on groundwater flow and solute transport in a nearshore aquifer. Water Resour. Res. 52, 990-1008. doi: 10.1002/2015WR017420

Zhou, Y., Sawyer, A. H., David, C. H., and Famiglietti, J. S. (2019). Fresh submarine groundwater discharge to the near-global coast. Geophys. Res. Lett. 46, 58555863. doi: 10.1029/2019GL082749

Zipperle, A., and Reise, K. (2005). Freshwater springs on intertidal sand flats cause a switch in dominance among polychaete worms. J. Sea Res. 54, 143-150. doi: 10.1016/j.seares.2005.01.003

Conflict of Interest: The authors declare that the research was conducted in the absence of any commercial or financial relationships that could be construed as a potential conflict of interest.

Copyright (C) 2019 Taniguchi, Dulai, Burnett, Santos, Sugimoto, Stieglitz, Kim, Moosdorf and Burnett. This is an open-access article distributed under the terms of the Creative Commons Attribution License (CC BY). The use, distribution or reproduction in other forums is permitted, provided the original author(s) and the copyright owner(s) are credited and that the original publication in this journal is cited, in accordance with accepted academic practice. No use, distribution or reproduction is permitted which does not comply with these terms. 